\title{
Long-term potentiation at CA3-CA1 hippocampal synapses with special emphasis on aging, disease, and stress
}

\author{
Ashok Kumar* \\ Department of Neuroscience, McKnight Brain Institute, University of Florida, Gainesville, FL, USA
}

\section{Edited by:}

Paula I. Moreira, University of Coimbra,

Portugal

\section{Reviewed by:}

Ángel M. Carrión, Universidad Pablo de

Olavide de Sevilla, Spain

Michael R. Foy, Loyola Marymount

University, USA

Rodrigo A. Cunha, University of

Coimbra, Portugal

${ }^{*}$ Correspondence:

Ashok Kumar, Department of

Neuroscience, McKnight Brain

Institute, University of Florida, PO Box

100244, Gainesville, FL 32610-0244,

USA.

e-mail:kash@mbi.ufl.edu
Synaptic plasticity in the mammalian central nervous system has been the subject of intense investigation for the past four decades. Long-term potentiation (LTP), a major reflection of synaptic plasticity, is an activity-driven long-lasting increase in the efficacy of excitatory synaptic transmission following the delivery of a brief, high-frequency train of electrical stimulation. LTP is regarded as a principal candidate for the cellular mechanisms involved in learning and offers an attractive hypothesis of how memories are constructed. There are a number of exceptional full-length reviews published on LTP; the current review intends to present an overview of the research findings regarding hippocampal LTP with special emphasis on aging, diseases, and psychological insults.

Keywords: aging, brain, hippocampus, LTP, stress, Alzheimer's disease

\section{INTRODUCTION}

Over the past 30 years, extensive research has provided an enormous amount of data on the characteristics underlying the cellular and molecular mechanisms of synaptic plasticity. The Polish psychologist, Konorski (1948), first introduced the term "synaptic plasticity" to describe persistent and activity-dependent changes in synaptic strength. Several forms of long-lasting synaptic plasticity have been observed in the mammalian central nervous system (CNS); long-term potentiation (LTP); and long-term depression (LTD) represent two major forms of neuronal plasticity. LTP is a long-lasting activity-dependent enhancement in excitatory synaptic strength following the delivery of a brief, high-frequency train of electrical stimulation, while LTD is long-lasting decrease in synaptic efficacy following a low-frequency stimulation. LTP, along with other forms of synaptic plasticity is generally considered the closest neural model for the cellular mechanism involved in learning and memory storage (Bliss and Collingridge, 1993; Abel et al., 1997; Malenka and Nicoll, 1999; Martin et al., 2000; Lynch, 2004; Malenka and Bear, 2004).

Originally, LTP was discovered at excitatory glutamatergic synapses between perforant path fibers originating from the entorhinal cortex and granule cells in the dentate gyrus of the hippocampus of a rabbit in vivo (Bliss and Gardner-Medwin, 1973; Bliss and Lomo, 1973). Subsequently, LTP has been investigated in a variety of mammalian species utilizing in vitro approaches including rat (Douglas and Goddard, 1975), mouse (Nosten-Bertrand et al., 1996), guinea pig (Harris and Cotman, 1986), monkey (Urban et al., 1996), and human (Chen et al., 1996; Beck et al., 2000; Cordoba-Montoya et al., 2010). Since its initial demonstration in the hippocampus (Bliss and Gardner-Medwin, 1973; Bliss and Lomo, 1973; Douglas and Goddard, 1975), LTP has been observed in various brain regions throughout the mammalian CNS, including the amygdala (Clugnet and LeDoux, 1990; Rogan et al., 1997; Sigurdsson et al., 2007), cortex (Artola and Singer, 1987; Teyler, 1989; Jung et al., 1990; Tsumoto, 1990; Kirkwood et al., 1993; Fox, 2002), striatum (Calabresi et al., 1992; Charpier and Deniau, 1997; Lovinger, 2010), ventral tegmental area (Nugent et al., 2007, 2008), cerebellum (Salin et al., 1996; Lev-Ram et al., 2002), and nucleus accumbens (Pennartz et al., 1993; Kombian and Malenka, 1994; Schotanus and Chergui, 2008). LTP can be observed both in vitro as well as in vivo condition.

The pioneering work of Bliss and Lomo (1973) encouraged numerous investigators to pursue research in understanding the attributes of LTP. The relevance and great amount of interest within the neuroscience community in researching LTP can be easily established by performing a simple search on PubMed; there were hardly 30 publications just after the discovery of LTP (1973-1980) but currently, there are over 8000 research articles published on the topic and this list is growing every day. Although it has been almost 40 years since the discovery of LTP, it is still a remarkably attractive research topic and a paragon of immense importance to all of us who are involved in understanding its clandestine nature. Many outstanding full-length review articles have been published on LTP (Bliss and Collingridge, 1993; Bear and Malenka, 1994; Malenka, 1994, 2003; Collingridge and Bliss, 1995; Malenka and Nicoll, 1999; Sanes and Lichtman, 1999; Malenka and Bear, 2004; Cooke and Bliss, 2006; Joels and Krugers, 2007; Sigurdsson et al., 2007; Abraham and Williams, 2008; Blundon and Zakharenko, 2008; Kerchner and Nicoll, 2008; Sacktor, 2008; Feldman, 2009; Minichiello, 2009; O’Dell et al., 2010; Vogt and Canepari, 2010; Baudry et al., 2011). This current article intends to present a brief summary of the research findings on LTP in the hippocampus, including induction, characteristics, cellular mechanisms, and modulation with special emphasis on aging, pathological conditions, and stress. 


\section{INDUCTION PROTOCOLS}

Since the pioneering discovery of LTP induction via a brief burst of high-frequency $(100 \mathrm{~Hz})$ electrical stimulation, various physiological stimulation paradigms have been employed to induce LTP. Because $100 \mathrm{~Hz}$ is not a rate at which neurons normally fire, the pursuit of more physiological naturally occurring firing patterns led to the discovery of several stimulation protocols. Under natural conditions, when a mouse or rat is exploring, hippocampal pyramidal neurons fire action potentials at a frequency of about $5 \mathrm{~Hz}$, resulting in what is known as "theta rhythm," a sinusoidal oscillation of the hippocampal electroencephalography, which is critical for mnemonic processing (Bland, 1986). This frequencyled investigators to develop theta burst stimulation (TBS) and primedburst stimulation (PBS) protocols (Larson and Lynch, 1986; Rose and Dunwiddie, 1986). TBS consists of three trains of stimuli delivered $20 \mathrm{~s}$ apart. Each train is composed of 10 stimulus epochs delivered at $5 \mathrm{~Hz}$ (200 ms apart) with each epoch consisting of four pulses at $100 \mathrm{~Hz}$ (Figure 1A). PBS includes a single priming pulse followed 170-200 ms later by a burst of stimuli delivered at 100$200 \mathrm{~Hz}, 200 \mathrm{~ms}$ apart (Figure 1B). Various modifications have been made to these protocols in many different studies. Although less physiological, another stimulation protocol used to elicit LTP is a 200-Hz stimulation (Grover and Teyler, 1990). Thus, brief and highfrequency stimulation protocols are usually employed to induce LTP, but there are several studies that have reported induction of LTP by low-frequency stimulation (Mayford et al., 1995; Thomas et al., 1996; Lante et al., 2006; Huang and Kandel, 2007; Habib and Dringenberg, 2009, 2010). For example, O'Dell's lab demonstrated LTP induction by single pulse at 5 or $10 \mathrm{~Hz}$ stimulation (900 pulses; Mayford et al., 1995; Thomas et al., 1996), and other studies have established LTP following prolonged $1 \mathrm{~Hz}$ stimulation
(Li et al., 1998; Lante et al., 2006; Huang and Kandel, 2007; Habib and Dringenberg, 2009, 2010). Our work also demonstrates induction of LTP following low-frequency stimulation ( $5 \mathrm{~Hz}, 900$ pulses) under a blockade of $\mathrm{Ca}^{2+}$ release from intracellular stores (ICS) during senescence (Kumar and Foster, 2004). However, the lowfrequency stimulation paradigm is not usually used to induce LTP, and more research is needed to clearly delineate the mechanisms that contribute to this type of LTP and learn how they may differ from those underlying high frequency-induced LTP.

\section{TYPES AND PHASES OF LTP}

Different areas of the brain exhibit different forms of LTP, which further depend on a number of factors including age of the organism and stimulation protocol. Depending upon the reliance of LTP on the $N$-methyl-D-aspartate (NMDA) receptor, two major types of LTP, NMDA receptor-dependent, and NMDA receptor-independent, have been identified (Grover and Teyler, 1992; Cavus and Teyler, 1996). For example, LTP induced at the CA3-CA1 hippocampal synapses employing high-frequency stimulation or TBS is dependent on the NMDA receptor (Collingridge et al., 1983; Harris et al., 1984; Morris et al., 1986), while an NMDA-independent form of LTP can be induced at the same synapse by using either a 200Hz stimulation protocol (Grover and Teyler, 1990; Grover, 1998), tetraethylammonium application (Powell et al., 1994), or activation of metabotropic G-protein coupled receptors (Bashir et al., 1993; Bortolotto and Collingridge, 1993; Bortolotto et al., 1999; Fernandez de Sevilla et al., 2008; Anwyl, 2009; Fernandez de Sevilla and Buno, 2010). LTP at mossy fiber-CA3 synapses is sustained by NMDA receptors (Rebola et al., 2008). Another example of NMDAindependent LTP is that which is induced by high-frequency stimulation at the mossy fiber pathway in the hippocampus (Harris and

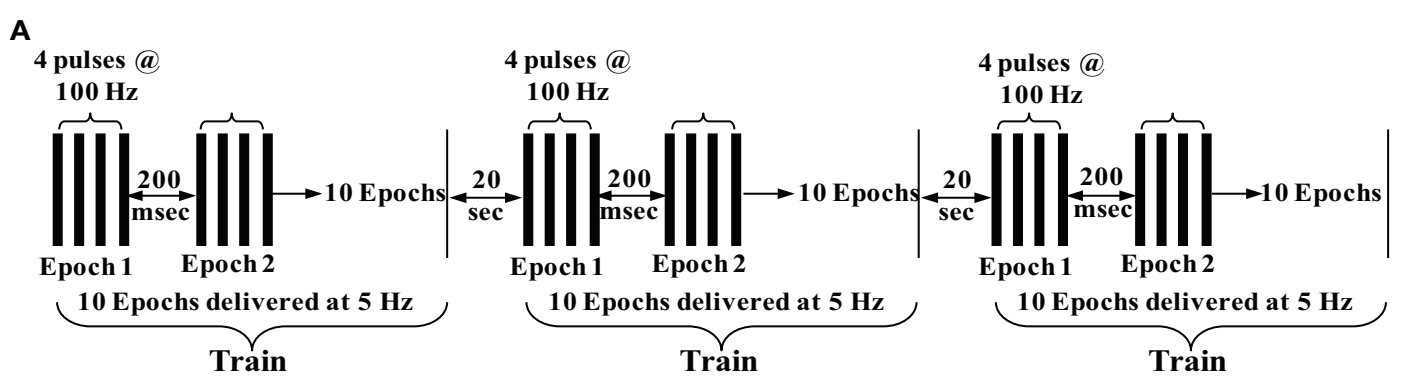

Theta Burst Stimulation (TBS)

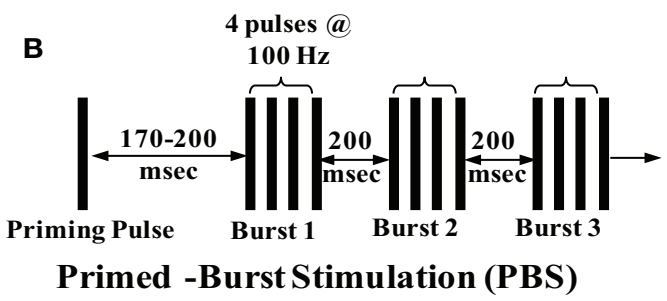

FIGURE 1 | Schematic depiction of standard theta burst stimulation and primed-burst stimulation. (A)TBS consists of three trains of stimuli delivered $20 \mathrm{~s}$ apart. Each train is composed of 10 stimulus epochs delivered at $5 \mathrm{~Hz}(200 \mathrm{~ms}$ apart) with each epoch consisting of four pulses at $100 \mathrm{~Hz}$. (B) PBS consists of a single priming pulse followed $170-200 \mathrm{~ms}$ later by a burst of stimuli delivered at $100-200 \mathrm{~Hz}$ (200 ms apart). 
Cotman, 1986). To avoid ambiguity, this review will focus on the NMDA receptor-dependent form of LTP at Schaffer-collateral/ commissural synapses in area CA1 of rat and mouse hippocampus.

Long-term potentiation is a multiphasic phenomenon and current models divide LTP into at least three different phases: an initial LTP (I-LTP), early LTP (E-LTP), and late LTP (L-LTP; Frey et al., 1993; Roberson et al., 1996; Sweatt, 1999), although an intermediate phase of LTP has also been suggested (Winder et al., 1998). I-LTP, also referred to as short-term potentiation, represents the foremost stage of LTP and is a continual form of NMDA receptor-dependent synaptic plasticity. I-LTP lasts about 30-60 min and does not require protein kinase activity (Roberson et al., 1996). E-LTP, which is evoked by fewer tetanic stimuli and lasts $2-3 \mathrm{~h}$, is also independent of protein kinase activity (Frey et al., 1993). L-LTP, induced by delivery of multiple tetanic stimuli, lasts $5-6 \mathrm{~h}$ and requires protein synthesis and gene expression (Frey et al., 1993). For more details regarding phases of LTP, readers are recommended to consult two recently published books (Sweatt, 2003; Andersen et al., 2007).

\section{PROPERTIES OF NMDA RECEPTOR-DEPENDENT LTP}

Long-term potentiation at the Schaffer-collateral pathway exhibits several basic characteristics which make it an attractive neural candidate for the storage of information; these include the principles of associativity, cooperativity, input-specificity, and persistence. The associativity principle indicates that a weak tetanic stimulation, activating few fibers, is insufficient for the induction of LTP. However, simultaneous strong stimulation of a neighboring pathway will trigger LTP at both synaptic pathways (Levy and Steward, 1979). Cooperativity occurs when a weak stimulation is paired with a strong postsynaptic depolarization. In this case, LTP will occur only when depolarization of postsynaptic cell occurs within about $100 \mathrm{~ms}$ of transmitter release from the presynaptic cell. Inputspecificity stipulates that LTP will occur only in synapses which received tetanic stimulation, but inactive synapses that contact the same neuron will not share synaptic enhancement (Andersen et al., 1977; Lynch et al., 1977). Thus, these properties entail the conditional requirements needed for information storage. Finally, regarding persistence, LTP can last for several hours in the in vitro slice preparation and for many months in the freely moving animals (in vivo; Abraham, 2003), suggesting an ability for sustained physiological change consistent with memory formation.

\section{CELLULAR/MOLECULAR MECHANISMS INVOLVED IN LTP}

Coincidence detection and temporal integration, two major aspects of dendritic integration, depend critically on the spatial and temporal properties of the dendritic summation of synaptic inputs (Magee, 2000; Segev and London, 2000). Changes in neuronal activity capable of inducing LTP lead to enhanced linearity of the spatial summation of synchronous excitatory postsynaptic potentials. Neuronal activity is likely to regulate dendritic integration of synaptic inputs. Bidirectional changes in the summation of excitatory postsynaptic potentials accompanying synaptic plasticity (LTP/LTD) are induced by correlated presynaptic and postsynaptic activity; induction of LTP at CA3-CA1 hippocampal synapses leads to persistent augmentation of dendritic summation of two Schaffercollateral inputs and summation occurs only at the potentiated input (Wang et al., 2003; Xu et al., 2006).
Multiple molecular and cellular mechanisms throughout the CNS contribute to induction, expression, and maintenance of LTP. An array of amino acid receptors including the NMDA receptor are involved in the induction of LTP. Induction of E-LTP occurs when the intracellular concentration of $\mathrm{Ca}^{2+}$ inside the postsynaptic cell exceeds a critical threshold. The transient influx of $\mathrm{Ca}^{2+}$ into the cell requires the NMDA receptors, which are ionotropic non-selective cationic glutamate receptors that play a central role in the rapid regulation of synaptic plasticity. Activation of NMDA receptors requires binding of a ligand (glutamate), membrane depolarization to remove the $\mathrm{Mg}^{2+}$ block of the channel, and binding of a co-agonist (glycine). Thus, these receptors behave like a molecular coincidence detector by allowing ionic flux only when the above conditions are met. Since the NMDA receptor is a non-selective cation channel, its activation and opening leads to simultaneous influx of $\mathrm{Na}^{+}$and $\mathrm{Ca}^{2+}$ ions (Chen et al., 2005), although they are the predominant ionotropic glutamate receptor subtype most permeable to $\mathrm{Ca}^{2+}$ ions (Jahr and Stevens, 1993; Garaschuk et al., 1996).

A tetanic stimulation of presynaptic fibers causes release of neurotransmitters, mainly glutamate, onto the postsynaptic cell membrane. The binding of glutamate to postsynaptic $\alpha$-amino3-hydroxy-5-methyl-4-isoxazolepropionic acid (AMPA) receptors triggers the influx of positively charged sodium ions into the postsynaptic cell and causes the cell to depolarize. The magnitude of depolarization determines the amount of $\mathrm{Ca}^{2+}$ entry into the postsynaptic cell. If the degree of depolarization is sufficient to remove the $\mathrm{Mg}^{2+}$ block of the NMDA receptor, then the channel will allow influx of $\mathrm{Ca}^{2+}$ into the cell. $\mathrm{Ca}^{2+}$ signal is necessary for the induction of LTP, which determines the degree and duration of LTP. The rapid rise in intracellular $\mathrm{Ca}^{2+}$ concentration triggers the activation of several enzymes, specifically kinases, such as calcium/ calmodulin-dependent protein kinase II (CaMKII) and protein kinase C (PKC), that mediate induction of E-LTP (Sweatt, 1999). CaMKII is a multi-subunit (10-12) enzyme and each of the subunits has a catalytic domain and an autophosphorylation domain. Activation of CaMKII by $\mathrm{Ca}^{2+}$ and calmodulin can autophosphorylate the enzyme, which will remain active independent of the continued presence of $\mathrm{Ca}^{2+}$ (Lisman, 1994). PKC has a regulatory domain and a catalytic domain and can be activated by a variety of second messengers including $\mathrm{Ca}^{2+}$, diaglycerol, arachidonic acid, and other phospholipids (Nishizuka, 1992). Activation of PKC in response to a rise in $\mathrm{Ca}^{2+}$ is transient, but $\mathrm{PKC}$ can be phosphorylated in an autonomous manner without the continued presence of $\mathrm{Ca}^{2+}$ (Inoue et al., 1977). CaMKII and PKCs play an important role in induction of E-LTP, and their ability to autophosphorylate, independent of second messengers, plays an essential role in maintenance of E-LTP (Klann et al., 1993; Sacktor et al., 1993; Lisman, 1994; Sacktor, 2008).

Late LTP is the natural extension of E-LTP and represents the final phase of LTP. The hallmark of L-LTP is the requirement of gene transcription and its dependence upon protein synthesis (Frey et al., 1988; Frey and Morris, 1997; Kelleher et al., 2004). A transient rise in $\mathrm{Ca}^{2+}$ concentration, due to influx through NMDA receptors, stimulates $\mathrm{Ca}^{2+}$-sensitive adenylyl cyclase enzymes, which catalyze production of $3^{\prime}, 5^{\prime}$-cyclic adenosine monophosphate (cAMP; Chetkovich et al., 1991; Chetkovich and Sweatt, 1993; Frey et al., 1993; Xia and Storm, 2005). The rise in cAMP activates another 
group of protein kinases, including protein kinase A (PKA; Huang et al., 1996). The phosphorylated PKA can activate mitogen-activated protein kinases, specifically extracellular regulated kinase (ERK). Once activated, ERK phosphorylates transcription factors, such as cAMP-response element-binding protein (CREB). Results suggest that transducers of regulated CREB (TORC), which are potent regulators of CREB activity, play a pivotal role in molecular mechanisms involved in L-LTP (Kovacs et al., 2007). The phosphorylated CREB activates the cAMP-response element, which induces changes in gene transcription and triggers synthesis of new proteins (Impey et al., 1996; Sweatt, 1999), many of which are yet to be determined. Downstream regulatory element antagonist modulator (DREAM) protein, calsenilin, has been recently suggested to be involved in LTP at perforant path-dentate gyrus molecular layer synapses; an impairment in LTP has been observed in calsenilin knockout mice (Lilliehook et al., 2003). However, a recent study demonstrated that LTD but not LTP was impaired in DREAM knockout mice at the hippocampal CA1 region (Wu et al., 2010).

The basic question as to whether the mechanisms underlying LTP, both the causes and locus of expression, result from changes in presynaptic or postsynaptic function remains contentious, for more details see Bekkers and Stevens (1990), Kullmann and Nicoll (1992), Isaac et al. (1995), Liao et al. (1995), Bolshakov et al. (1997), Debanne et al. (1997), Routtenberg (1999), Zakharenko et al. (2001), Emptage et al. (2003), Martin and Buno (2003), Nicoll (2003), Huang et al. (2005), Bayazitov et al. (2007), Lauri et al. (2007), Fernandez de Sevilla et al. (2008), Kerchner and Nicoll (2008), and Cabezas and Buno (2011). For more details about molecularcellular mechanisms of LTP, readers are referred to several informative reviews published over the course of three decades (Madison and Schuman, 1991; Bliss and Collingridge, 1993; Malenka, 1994, 2003; Roberson et al., 1996; Nicoll and Malenka, 1999; Sanes and Lichtman, 1999; Sweatt, 1999; Bredt and Nicoll, 2003; Malenka and Bear, 2004; Shi et al., 2005; Miyamoto, 2006; Kerchner and Nicoll, 2008; Minichiello, 2009; Li et al., 2010a; Baudry et al., 2011; Kelly et al., 2011a).

\section{THE ROLE OF Ca ${ }^{2+}$ IN INDUCTION OF LTP}

As stated previously, LTP can be induced by a wide variety of stimulation paradigms, and in all cases, induction of LTP requires a substantial rise in intracellular $\mathrm{Ca}^{2+}$. Thus, a $\mathrm{Ca}^{2+}$ signal is necessary for the induction of LTP and its regulation plays a significant role in determining the degree and duration of LTP. The major sources of intracellular $\mathrm{Ca}^{2+}$ include $\mathrm{Ca}^{2+}$ influx through ligandgated glutamate receptors, such as NMDA receptors or various voltage-dependent $\mathrm{Ca}^{2+}$ channels (VDCCs), as well as the release of $\mathrm{Ca}^{2+}$ from ICS (Ghosh et al., 1994; Geiger et al., 1995; Berridge, 1998; Kumar and Foster, 2004).

It is generally accepted that at CA1 hippocampal synapses, NMDA receptors provide the foremost source of $\mathrm{Ca}^{2+}$ for LTP induction following stimulation frequencies near the threshold for synaptic modification (Johnston et al., 1992; Cavus and Teyler, 1996). However, the level of $\mathrm{Ca}^{2+}$ in dendritic spines can be influenced by VDCCs, ICS, and other glutamate receptors (Jaffe et al., 1994; Christie et al., 1996, 1997; Dingledine et al., 1999; Korkotian and Segal, 1999). Interestingly, several studies have shown that VDCCs and ICS are involved in regulating the threshold for induction of synaptic modification (Foster and Norris, 1997; Norris et al., 1998; Wilsch et al., 1998; Rose and Konnerth, 2001; Foster and Kumar, 2002; Raymond and Redman, 2002; Kamsler and Segal, 2003; Kumar and Foster, 2004). Readers are referred to many excellent previously published articles for more details about the role of $\mathrm{Ca}^{2+}$ in LTP (Foster and Kumar, 2002; Atkins et al., 2005; MacDonald et al., 2006; Miyamoto, 2006; Tonkikh et al., 2006; Foster, 2007; Kumar et al., 2009; Simons et al., 2009; Barnes et al., 2010; Burke and Barnes, 2010; Diez-Guerra, 2010; Yoshioka et al., 2010; Munoz et al., 2011).

\section{REGULATION/NEUROMODULATION OF LTP}

Neuromodulators, such as norepinephrine, serotonin, dopamine, acetylcholine, and histamine affect the induction of LTP and control the endurance of synaptic facilitation at Schaffer-collateral synapses. The hippocampus is densely innervated with noradrenergic (Cooper et al., 2003), cholinergic (Lewis et al., 1967; Amaral and Kurz, 1985; Frotscher and Leranth, 1985; Gaykema et al., 1990), dopaminergic (Gasbarri et al., 1994a,b; Goldsmith and Joyce, 1994), serotonergic (Storm-Mathisen and Guldberg, 1974; Azmitia and Segal, 1978), and histaminergic (Panula et al., 1989) nerve terminals from the locus coeruleus, the medial septum-diagonal band complex, the substantia nigra-ventral tegmental area, dorsal-medial raphe nuclei, and tuberomammillary nucleus of the posterior hypothalamus, respectively. The endogenous release of neurotransmitters or agents acting on the receptors of these transmitter systems has the potential to regulate the induction of LTP. Readers interested in more details of the roles of various neurotransmitters in modulating LTP are advised to consult several previously published articles (Williams and Johnston, 1988; Blitzer et al., 1990; Staubli and Otaky, 1994; Brown et al., 1995; Otmakhova and Lisman, 1996; Wang and Arvanov, 1998; Costenla et al., 1999, 2010; Leung et al., 2003; Li et al., 2003; Tachibana et al., 2004; Doralp and Leung, 2008; Rebola et al., 2008; Buchanan et al., 2010; Fernandez de Sevilla and Buno, 2010; Luo and Leung, 2010; O’Dell et al., 2010; Swant et al., 2010).

Long-term potentiation can be modulated by a range of other agents, including corticosteroids (Foy et al., 1987; Diamond et al., 1989; Pavlides et al., 1993; McEwen, 1994; Sabeti et al., 2007; Maggio and Segal, 2010), caffeine (Lee et al., 1987; Lu et al., 1999a; Martin and Buno, 2003; Sajikumar et al., 2009; Alhaider et al., 2010; Costenla et al., 2010; Maggio and Segal, 2010), estrogen (Foy et al., 1999, 2001, 2008a,c), endocannabinoids (Terranova et al., 1995; Misner and Sullivan, 1999; Carlson et al., 2002; Chevaleyre and Castillo, 2004; Slanina et al., 2005; Chevaleyre et al., 2006, 2007; Abush and Akirav, 2010), flavonoids (Wang et al., 2011), inhibitors of histone deacetyltransferase activity (Alarcon et al., 2004; Haettig et al., 2011), neurotrophic factors (Kang and Schuman, 1995; Gottschalk et al., 1998; Korte et al., 1998; Xu et al., 2000; Kovalchuk et al., 2002; Fontinha et al., 2008; Sallert et al., 2009; Xie et al., 2010), nitric oxide/carbon monoxide (Bohme et al., 1991; Bon et al., 1992; Izumi et al., 1992, 2008; Zhuo et al., 1993, 1994, 1999; O’Dell et al., 1994; Arancio et al., 1996; Lu et al., 1999b; Taqatqeh et al., 2009; Carlini et al., 2010), purines (Wieraszko and Ehrlich, 1994; Costenla et al., 1999, 2010; Yamazaki et al., 2003; Fujii, 2004; Rebola et al., 2008; Maggi et al., 2009; Dias et al., 2011), orexin (Aou et al., 2003; Akbari et al., 2011), reducing agents (Tauck and 
Ashbeck, 1990; Gozlan et al., 1995; Cai et al., 2008; Bodhinathan et al., 2010b; Cowley et al., 2011; Kelly et al., 2011b), and oxidizing agents (Watson et al., 2006). The presence of action potentials in the dendrites, which are mainly regulated by A-type potassium channels, can modulate induction of LTP (Magee and Johnston, 1997; Murphy et al., 1997; Johnston et al., 2000, 2003; Watanabe et al., 2002; Kim et al., 2007; Jung et al., 2011). Finally, metaplasticity, which refers to activity-dependent modulation of subsequent synaptic plasticity (Abraham and Bear, 1996; Abraham and Tate, 1997), can modulate LTP. In this case, previous activity/experience can influence the ability of hippocampal CA1 synapses to undergo subsequent synaptic facilitation, for details see Abraham and Bear (1996), Abraham and Tate (1997), Wang and Wagner (1999), Abraham et al. (2001), Jung et al. (2008), Sajikumar et al. (2009), Motanis and Maroun (2010), and Narayanan and Johnston (2010).

\section{LTP DURING AGING}

Aging is associated with decline in cognitive function, including learning and memory. Hippocampal-dependent spatial and episodic memory tasks, such as recently acquired verbal recall, are significantly impaired as a result of aging (Hulicka and Rust, 1964; Bruning et al., 1975; Giambra and Arenberg, 1993; Head et al., 2008; Lister and Barnes, 2009). Senescent physiology, including altered hippocampal synaptic plasticity, is thought to contribute to the decline in cognitive function associated with aging and age-associated neurodegenerative diseases (Barnes, 1979, 2003; Disterhoft et al., 1994; Lynch, 1998a; Rosenzweig and Barnes, 2003; Tombaugh et al., 2005; Disterhoft and Oh, 2006; Foster and Kumar, 2007; Lister and Barnes, 2009). In general, no age-related differences are observed in the magnitude of LTP (Landfield et al., 1978; Barnes, 1979; Deupree et al., 1993; Moore et al., 1993; Diana et al., 1994a; Norris et al., 1996; Shankar et al., 1998), however, aging is associated with a shift in synaptic plasticity favoring decreased synaptic transmission and a reduced ability to induce LTP (Landfield and Lynch, 1977; Landfield et al., 1978; Barnes, 1979, 1990, 1994; de Toledo-Morrell and Morrell, 1985; Davis et al., 1993; Deupree et al., 1993; Moore et al., 1993; Lynch and Voss, 1994; Auerbach and Segal, 1997; Lynch, 1997, 1998a,b; McGahon et al., 1997; Murray and Lynch, 1998a,b; Shankar et al., 1998; Hsu et al., 2002; Watson et al., 2002, 2006; Blank et al., 2003; Rosenzweig and Barnes, 2003; Watabe and O'Dell, 2003; Griffin et al., 2006; Kelly et al., 2011b). It has been suggested that impairment of LTP may begin in middle age (Rex et al., 2005) and a shift in synaptic plasticity, favoring LTD over LTP, contributes to the decrease in synaptic transmission observed in aged animals (Foster, 1999). Aged, memory-impaired animals exhibit deficits in LTP induction, and altered hippocampal synaptic plasticity is one of the hallmarks of age-associated memory impairment in mammals (Foster, 1999; Tombaugh et al., 2002; Barnes, 2003; Rosenzweig and Barnes, 2003; Burke and Barnes, 2010). Results also suggest that aging is associated with an increase in LTP (Costenla et al., 1999).

In considering synaptic transmission during aging, it is important to note that the observed shift in synaptic modifiability is not due to a change in the expression mechanisms. For example, there is no age-related difference in the maximal LTP magnitude observed under conditions in which a strong burst of synaptic stimulation is delivered (Diana et al., 1994b; Norris et al., 1996; Shankar et al., 1998). In addition, significant LTP can be observed in aged animals when single pulses are combined with strong postsynaptic depolarization or weak stimulation is combined with increased $\mathrm{Ca}^{2+}$; our work, too, demonstrates that asymptotic LTP can be induced in aged animals by employing multiple episodes of TBS (Figure 2; Barnes et al., 1996; Watabe and O’Dell, 2003; Kumar et al., 2007). This suggests that signaling pathways for the induction of LTP are intact during senescence. In contrast, it has been shown that the threshold for LTP induction is increased in aged memory-impaired animals (Landfield et al., 1978; Deupree et al., 1993; Moore et al., 1993; Barnes et al., 1996; Norris et al., 1996; Foster and Kumar, 2007), due in part to impaired postsynaptic depolarization. Thus, during aging, there may be a shift in the mechanisms that regulate the induction (i.e., threshold) of synaptic plasticity rather than a loss of expression mechanisms (Kumar et al., 2007). This shift

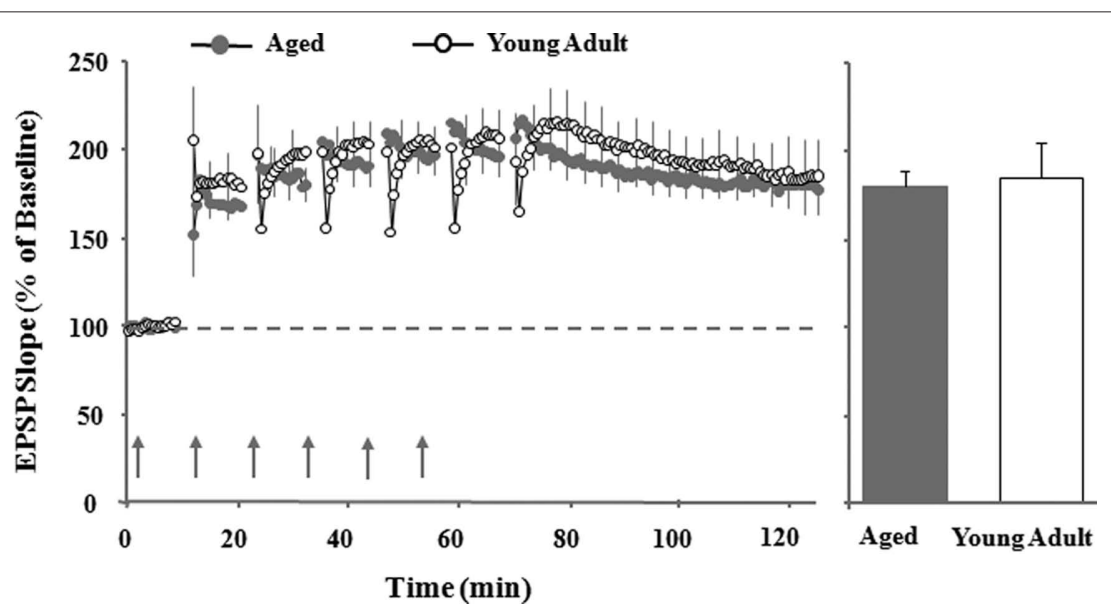

FIGURE 2 | Multiple episodes of theta burst stimulation (TBS) induced maximal LTP, which is of similar amplitude in young adult and aged rats. Illustration of individual excitatory postsynaptic potentials from aged (gray circle) and young adult (open circle) rats before (10 min) and after
(60 $\mathrm{min}$ ) the last episode of TBS. Bar diagram represents mean percentage change in the slope of synaptic responses during the last $10 \mathrm{~min}$ of recording, 60 min following the sixth TBS episode (adapted from Kumar et al., 2007). 
may favor synaptic weakening and could act as a functional lesion, reducing the ability for information to be transmitted through the hippocampus.

The NMDA receptor component of the synaptic response is decreased in aged animals (Barnes et al., 1997; Foster, 1999, 2007; Rosenzweig and Barnes, 2003; Billard and Rouaud, 2007; Bodhinathan et al., 2010b). Supporting this, several studies have shown that NMDA receptors contribute less $\mathrm{Ca}^{2+}$ to the induction of LTP in area CA1 of aged hippocampus when compared to the young hippocampus (Norris et al., 1998; Shankar et al., 1998; Boric et al., 2008). Changes in subunit expression, composition, and splice variants of NMDA receptors may also contribute to age-associated deficits of NMDA receptor function (Magnusson et al., 2002, 2005, 2006, 2010). However, there is a debate concerning whether NMDA receptor subunit expression actually decreases at hippocampal CA3-CA1 synapses (Foster, 2002). In addition, it is possible that functional differences result from posttranslational modifications associated with oxidation or phosphorylation states of the receptor (Foster, 2007).

Previous research examining the ability of reducing and oxidizing (redox) agents to modulate NMDA receptor activity in cell cultures and in tissue from neonates suggests that redox state is an important determinant of NMDA receptor function (Aizenman et al., 1989, 1990; Bernard et al., 1997; Choi and Lipton, 2000; Choi et al., 2001), possibly through oxidation of extracellular cysteine residues on the NMDA receptor (Lipton et al., 2002). Intracellular signaling molecules that affect NMDA receptor function are also sensitive to redox state. The aged brain exhibits an increase in oxidative damage (Harman, 1956; Beckman and Ames, 1998; O'Donnell et al., 2000; Kamsler and Segal, 2004; Serrano and Klann, 2004; Foster, 2006; Poon et al., 2006; Pieta Dias et al., 2007; Li et al., 2010b) and a decrease in redox buffering capacity (Parihar et al., 2008). Recently, our work demonstrated that the age-related decline in NMDA receptor-mediated synaptic responses is clearly related to the redox state associated with aging (Bodhinathan et al., 2010b). In addition, evidence has been provided that NMDA receptor function may be compromised due to altered $\mathrm{Ca}^{2+}$ homeostasis leading to increased activity of the $\mathrm{Ca}^{2+}$-dependent phosphatase, calcineurin. Calcineurin activity depends on a modest rise in intracellular $\mathrm{Ca}^{2+}$, and aged memory-impaired animals exhibit an increase in calcineurin activity (Foster et al., 2001). In turn, calcineurin can act on NMDA receptors to reduce $\mathrm{Ca}^{2+}$ influx (Lieberman and Mody, 1994; Tong and Jahr, 1994).

The idea that induction of LTP is subdued as a result of a reduction in NMDA receptor activation during aging is supported by research showing that induction deficits can be overcome by strong postsynaptic depolarization (Barnes et al., 1996). Indeed, there are several reasons to believe that an inability to achieve sufficient postsynaptic depolarization, a prerequisite for NMDA receptor activation, may be more problematic for LTP induction during senescence. First, the reduced synaptic strength of aged animals may result in a reduced afferent cooperativity in depolarizing the postsynaptic neuron and an inability to reach the level of depolarization needed for NMDA receptor activation. Moreover, it has been proposed that the inability to depolarize the cell is compounded during patterned stimulation, due to the larger after hyperpolarization (AHP). In fact, results suggest that it is the relatively large AHP which underlies much of the LTP impairment found in these animals (Foster and Norris, 1997; Foster, 1999). Our work demonstrates that large AHP amplitude may mask the propensity of enhanced LTP induction during senescence (Kumar and Foster, 2004). Normally, there is a relationship between the frequency of afferent stimulation required for LTP induction and the level of resulting depolarization (Froemke et al., 2005), but during aging this is obscured by an increase in the $\mathrm{Ca}^{2+}$-dependent, $\mathrm{K}^{+}$-mediated AHP (Landfield and Pitler, 1984; Pitler and Landfield, 1990; Moyer et al., 1992; Disterhoft et al., 1996; Kumar and Foster, 2002; Tombaugh et al., 2005; Bodhinathan et al., 2010a). During aging, the large AHP may disrupt the integration of depolarizing postsynaptic potentials and the duration of this disruption has been proposed to be a function of the extent and duration of the AHP (Foster and Norris, 1997; Foster, 1999; Foster and Kumar, 2002). Hypothetically, the disruption would increase the level of stimulation needed for LTP, resulting in a plateau in the frequency-response function. In fact, our studies along with others, have demonstrated that the AHP amplitude is intimately involved in regulating the threshold for induction of LTP (Sah and Bekkers, 1996; Norris et al., 1998; Cohen et al., 1999; Sourdet et al., 2003; Kramar et al., 2004; Kumar and Foster, 2004; Le Ray et al., 2004; Murphy et al., 2004; Xu and Kang, 2005; Fuenzalida et al., 2007). Further, other evidence shows that pharmacological manipulations that reduce the AHP amplitude also shift the frequency-response functions, such that LTP can be observed following stimulation frequencies that would normally not elicit LTP. For example, pharmacological blockade of L-type $\mathrm{Ca}^{2+}$ channels, inhibition of $\mathrm{Ca}^{2+}$ release from ICS, or attenuation of $\mathrm{K}^{+}$channels enables the induction of LTP following a modest stimulation in aged animals (Figure 3; Norris et al., 1998; Kumar and Foster, 2004). Similarly, our work also demonstrates that LTP can be inhibited by enhancement in the amplitude of the AHP following treatment with the L-channel agonist, Bay K8644 (Figure 4; Kumar and Foster, 2004). Although L-channel activity should provide more $\mathrm{Ca}^{2+}$, the induction of LTP is impaired due to L-channel-induced enhancement in the AHP

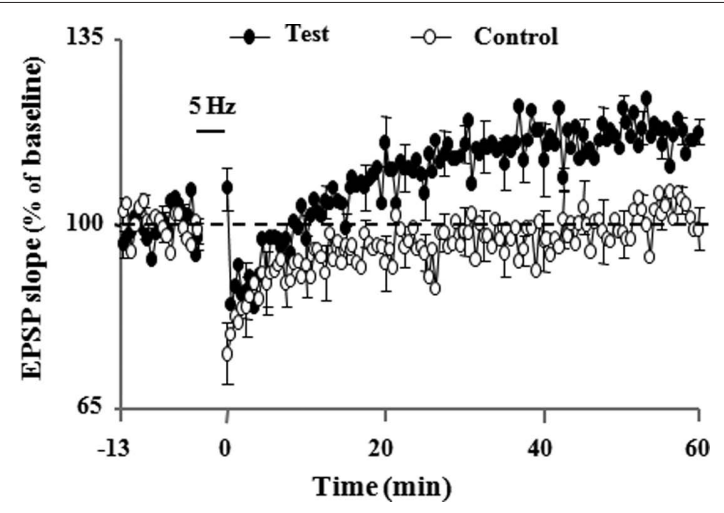

FIGURE 3 | Pharmacological inhibition of intracellular $\mathrm{Ca}^{2+}$ stores by cyclopiazonic acid (CPA; $3 \mu \mathrm{M}$ ) led to LTP induction by a low-frequency ( $5 \mathrm{~Hz}, 900$ pulses) stimulation protocol. Illustrations of the time course of mean percentage change in the synaptic responses during $10 \mathrm{~min}$ before and $60 \mathrm{~min}$ after delivery of $5 \mathrm{~Hz}$ stimulation $(5 \mathrm{~Hz} / 3 \mathrm{~min}$, solid horizontal line) to the control and test path. LTP is observed only in test path (adapted from Kumar and Foster, 2004). 

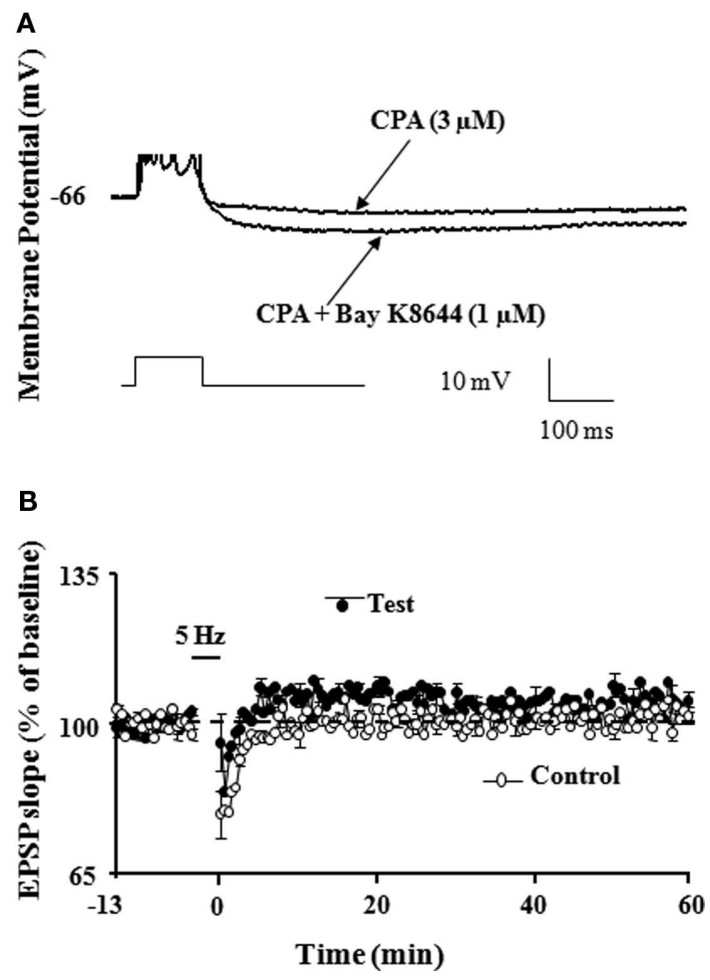

FIGURE 4 | Enhance AHP amplitude during aging contributes to impaired LTP induction. (A) Representative intracellular current clamp recordings from a CA1 hippocampal pyramidal neuron in aged rat are shown after a train of five action potentials elicited by a 100-ms pulse of depolarizing current under conditions of CPA $(3 \mu \mathrm{M})$ and following bath application of Bay K8644 $(1 \mu \mathrm{M})$ in the presence of CPA. Note that under conditions of blockade of $\mathrm{Ca}^{2+}$ release from intracellular calcium stores by CPA, the L-channel agonist, Bay K8644 increased the AHP amplitude. (B) Time course of the synaptic responses following $5 \mathrm{~Hz}$ pattern stimulation in presence of Bay K8644 + CPA. LTP induced by $5 \mathrm{~Hz}$ stimulation was blocked under conditions of Bay K8644 + CPA in which AHP amplitude was increased (adapted from Kumar and Foster, 2004).

amplitude. Thus, it is interesting to note that, while induction of LTP depends on a large rise in intracellular $\mathrm{Ca}^{2+}$, LTP induction is facilitated by blocking several $\mathrm{Ca}^{2+}$ sources that contribute to the AHP during senescence.

Another method for investigating the relationship between the AHP and LTP threshold is to reduce the AHP amplitude through manipulation of the potassium channels. For example, blockade of SK-type potassium channels by apamin increases cell excitability and facilitates induction of LTP (Norris et al., 1998). Moreover, deletion of the Kv $\beta 1.1$ subunit results in enhanced cell repolarization during repetitive firing by preventing A-type potassium channel inactivation. In turn, the normal spike broadening and increased $\mathrm{Ca}^{2+}$ influx through VGCCs is impaired by rapid repolarization. It follows then, that in Kv $\beta 1.1$ knockout mice, the AHP is reduced and LTP is facilitated (Murphy et al., 2004). These results indicate that the source of $\mathrm{Ca}^{2+}$ provides an overriding control of synaptic modifiability, shifting the threshold frequency for LTP induction.

NMDA receptor activation following high-frequency stimulation leads to a robust rise in $\mathrm{Ca}^{2+}$; this rise in $\mathrm{Ca}^{2+}$ activates $\mathrm{Ca}^{2+}-$ dependent protein kinases that phosphorylate proteins, such as the
GluR1 subunit of the AMPA receptor, which mediates the expression of LTP. In contrast, a modest rise in $\mathrm{Ca}^{2+}$ results in synaptic depression through activation of protein phosphatases that dephosphorylate AMPA receptors, for review, see Xia and Storm (2005). Thus, due to the differential level of $\mathrm{Ca}^{2+}$ involved in the generation of various forms of synaptic plasticity, any treatment that modifies $\mathrm{Ca}^{2+}$ influx to the cytoplasm can influence the direction and degree of synaptic plasticity. The dependence on intracellular $\mathrm{Ca}^{2+}$ levels in determining the specific form of synaptic plasticity coincides with the observation that stimulation patterns for the induction of LTP and synaptic depression tend to require high- and low-frequency patterns, respectively.

Theoretical models suggest that synaptic plasticity is a function of synaptic activity, such that low-frequency stimulation induces synaptic depression. As neural activity increases, there is a transition from net LTD to induction of LTP (Bienenstock et al., 1982; Artola and Singer, 1993). A basic assumption of these models is that the threshold frequency for synaptic modification can "slide," or is modifiable. Thus, changes in synaptic plasticity thresholds can be identified by plotting the change in synaptic strength as a result of different conditioning stimulation frequencies. This is referred to as the frequency-response function. The thresholds for induction of depression and LTP, as defined by afferent activity, are thought to reflect activity-dependent changes in the level of intracellular $\mathrm{Ca}^{2+}$, which in turn activates $\mathrm{Ca}^{2+}$-dependent enzymes.

Aging is associated with altered regulation of $\mathrm{Ca}^{2+}$ homeostasis (Landfield and Pitler, 1984; Gibson and Peterson, 1987; Khachaturian, 1989; Thibault et al., 1998, 2007; Mattson et al., 2000; Foster and Kumar, 2002; Toescu et al., 2004; Disterhoft and Oh, 2006; Foster, 2006, 2007; Mattson, 2007; Toescu and Verkhratsky, 2007; Kumar et al., 2009). The shift in $\mathrm{Ca}^{2+}$ homeostasis, increased amplitude of AHP, and altered $\mathrm{Ca}^{2+}$ signaling involving an alteration in the activity of phosphatases and kinases also give rise to increased susceptibility to induction of synaptic depression during senescence. In aged animals, blockade of NMDA receptors can reduce, but does not necessarily prevent, synaptic depression (Norris et al., 1998). These results indicate a shift in $\mathrm{Ca}^{2+}$ homeostasis such that aging cells exhibit reduced $\mathrm{Ca}^{2+}$ influx from NMDA receptors and an increased contribution from VGCCs and ICS during neural activity (Foster, 1999). In addition, it is likely that aged neurons exhibit changes in intracellular buffering and processes for extrusion of $\mathrm{Ca}^{2+}$. Collectively, this shift results in alterations in physiology, including an increase in the AHP amplitude and impaired LTP induction, at least under physiological $\mathrm{Ca}^{2+} / \mathrm{Mg}^{2+}$ conditions.

The change in $\mathrm{Ca}^{2+}$ homeostasis, which shifts the cell away from $\mathrm{Ca}^{2+}$ influx through NMDA receptors may be neuroprotective against $\mathrm{Ca}^{2+}$ mediated damage and thus act as compensation for increased vulnerability to neurotoxicity (Phillips et al., 1999). Alternatively, the shift in $\mathrm{Ca}^{2+}$ homeostasis could result from agerelated increase in oxidative stress (Squier, 2001; Annunziato et al., 2003; Serrano and Klann, 2004). Reactive oxygen species could induce a rise in intracellular $\mathrm{Ca}^{2+}$ through release of $\mathrm{Ca}^{2+}$ from $\mathrm{Ca}^{2+}$ binding proteins (i.e., decreased buffering) and oxidation of $\mathrm{Ca}^{2+}$ regulatory proteins (such as calmodulin) would disrupt ICS and increase entry through $\mathrm{Ca}^{2+}$ channels (Suzuki et al., 1997; Squier, 2001). In the hippocampus, oxidative stress has effects that mimic aging by increasing $\mathrm{Ca}^{2+}$ influx through L-channels (Lu et al., 2002; 
Akaishi et al., 2004), increasing the function of $\mathrm{Ca}^{2+}$-dependent $\mathrm{K}^{+}$ channels (Gong et al., 2000, 2002) and decreasing NMDA receptor function (Lu et al., 2001). Furthermore, oxygen radicals can influence the activity of $\mathrm{Ca}^{2+}$-dependent enzymes. The unstable super oxide (O·) or high levels of $\mathrm{H}_{2} \mathrm{O}_{2}$ (beyond the physiological range) inhibit calcineurin in tissue homogenates (Kamsler and Segal, 2003, 2004; Ullrich et al., 2003). However, in intact tissue, reactive oxygen species increase calcineurin activity, either through changes in the calcineurin inhibitory protein (Lin et al., 2003) or altered $\mathrm{Ca}^{2+}$ regulation involving increased $\mathrm{Ca}^{2+}$ from ICS and VGCCs, leading to impaired induction of LTP (Kamsler and Segal, 2004). Results from a series of studies by Marina Lynch's group elegantly demonstrated the role of oxygen free radicals and anti-oxidants in sustaining impaired LTP induced by age and stress associated neuroinflammation (Nolan et al., 2005; Griffin et al., 2006; Lynch et al., 2007a; Clarke et al., 2008; Loane et al., 2009; Cowley et al., 2011; Kelly et al., 2011b); for reviews see Lynch (2010). Future research will be required in order to determine whether treatments designed to reduce oxidative stress can reverse age-associated impaired LTP. The role of $\mathrm{Ca}^{2+}$ regulation has been a major focus of research for agerelated impairment in LTP and for more details readers are advised to consult the following review articles: (Disterhoft et al., 1994; Khachaturian, 1994; Landfield, 1994; Muller et al., 1996; Foster and Norris, 1997; Thibault et al., 1998, 2007; Verkhratsky and Toescu, 1998; Foster, 1999, 2006, 2007; Foster and Kumar, 2002; Toescu et al., 2004; Toescu and Verkhratsky, 2007; Kumar et al., 2009). Also, as suggested above, age-induced impairment in neuromodulation may contribute to the progression of senescent physiology, including impaired LTP and decline in cognitive function; for reviews see Potier et al. (1993), Disterhoft et al. (1999), Wu et al. (2002), Disterhoft and Matthew Oh (2003), Mesulam (2004), Backman et al. (2006), Billard (2006), Canas et al. (2009), Duzel et al. (2010), and Niewiadomska et al. (2009).

Aging is associated with an increased activation of microglia and astrocytes (Lynch et al., 2007a; Lyons et al., 2007), which may contribute to impaired LTP associated with senescence (Griffin et al., 2006; Lynch, 2010). Results are emerging which support that antagonists (minocycline, atorvastatin, rosiglitazone, or the polyunsaturated fatty acid, eicosapentaenoic acid), that inhibit glial activation, are capable of sustaining LTP in animals where it is normally compromised (Nolan et al., 2005; Griffin et al., 2006; Lynch et al., 2007a; Clarke et al., 2008; Loane et al., 2009; Cowley et al., 2011; Kelly et al., 2011b). Future studies are required to determine the role of microglia in LTP and underlying mechanisms.

\section{LTP DURING STRESS}

Stress, from mild anxiety to mental trauma, perilously disturbs biological, physiological, and psychological dynamic equilibrium; acute as well as chronic stress has a profound influence on brain-body interaction and considerably contributes to cognitive deficits (Foy et al., 1987; McEwen and Sapolsky, 1995; Kim et al., 1996; Kim and Yoon, 1998; McEwen, 1999, 2008; Kim and Diamond, 2002; Artola, 2008; van Stegeren, 2009; Wolf, 2009; Maggio and Segal, 2010; Rothman and Mattson, 2010; Foy, 2011). A stimulus that has the ability to induce stress causes release of corticosterone from the adrenal glands. Corticosterone acts on the corticosterone receptors, mineralocorticoid (MR) and glucocorticoid (GR), which are distributed throughout the body including the hippocampus (Reul and de Kloet, 1985; Patel et al., 2000), and produce an appropriate response to manage the stressful event. The classical view of the influence of stress on LTP and memory functions presumes an inverted U-shape curve, such that a low-mild stress level facilitates but a high level impairs LTP induction (Diamond et al., 1992; Joels, 2006); however, the inverted U-shape effect of stress on LTP is not fully explained by this model (Maggio and Segal, 2010). The discovery of membrane-bound corticosterone receptors, $\mathrm{mMR}$ and $\mathrm{mGR}$, which act through novel non-genomic pathways, can affect ionic conductances and modify cell excitability and function (Karst et al., 2005; Karst and Joels, 2005; de Kloet et al., 2008; van Gemert et al., 2009), in addition to two classical genomic nuclear corticosterone receptors, the MR and GR, which contribute to slow and persistent change in the function of cell (de Kloet et al., 1999; Joels, 2001), further complicates the influence of stress on LTP. Results from a recent study demonstrate that persistently augmented hippocampal corticotropin-releasing hormone and its interaction with corticotropin-releasing hormone receptor type 1 , which reside on dendrites of CA1 pyramidal cells, contributes to impairment in LTP and cognitive function associated with chronic early life stress (Ivy et al., 2010).

Long-term potentiation at the hippocampal synapses is virtually abolished following acute or chronic stress (Foy et al., 1987, 2008b; Shors et al., 1989; Xu et al., 1997; Pavlides et al., 2002; Alfarez et al., 2003; Diamond et al., 2005; Artola et al., 2006; Kavushansky et al., 2006; Foy, 2011). However, LTP can still be induced during stress by employing higher effective postsynaptic depolarization (Artola et al., 2006). Further, depending upon the brain area, stress influences LTP differently. For example, chronic psychological stress impairs LTP induction in hippocampal area CA1, while it has no effect on dentate gyrus LTP (Gerges et al., 2001). Similarly, acute stress or physiological concentrations of corticosterone can inhibit induction of LTP in dorsal hippocampus while LTP is facilitated in the ventral hippocampus (Maggio and Segal, 2007, 2011). In addition, corticosterone facilitates VDCC-dependent LTP while NMDA-dependent LTP is impaired in the CA1 area of the hippocampus (Krugers et al., 2005; Maggio and Segal, 2007). Stress evoked by opiate withdrawal facilitates LTP (Dong et al., 2006). The concentration of cGMP depends on the rates of synthesis by soluble guanylyl cyclase and degradation by phosphodiesterase (PDE). PDEs are implicated in modulation of LTP (Barad et al., 1998; Kuenzi et al., 2003; Navakkode et al., 2004). Results from a recent study suggest that enhanced cAMP-specific PDE4 activity contributes to impaired LTP associated with acute stress (Chen et al., 2010a). The effects of stress (behavior, acute, chronic, fear, escape, traumatic brain injury) on LTP in the hippocampus are well documented (Foy et al., 1987, 2008b; Shors et al., 1989, 1997; Diamond et al., 1994; Diamond and Rose, 1994; Garcia et al., 1997; Xu et al., 1997; Albensi et al., 2000; O’Donnell et al., 2000; Vereker et al., 2001; Alfarez et al., 2002, 2003; Pavlides et al., 2002; Gerges et al., 2004; Rocher et al., 2004; Hui et al., 2005; Li et al., 2005; Schwarzbach et al., 2006; Kim and Haller, 2007; Kohda et al., 2007; Artola, 2008; Ryan et al., 2008; Ivy et al., 2010; Kamal et al., 2010; Sterlemann et al., 2010; Tran et al., 2010; Maggio and Segal, 2011). Overall, results suggest that stress profoundly influences the induction of LTP; intensity of stress (mild, acute, chronic) and area of the hippocampus (CA1, DG, ventral or dorsal hippocampus) play 
critical roles in determining the degree and direction of stressinduced alteration in the LTP. Future studies will resolve the role of specific receptor types and signaling mechanisms contributing to stress-induced alterations in synaptic potentiation.

In general, aging and stress both negatively influence induction of LTP; there are several commonalities between advanced age and stress, including enhanced neuroinflammation and oxidative stress, which could contribute to impaired LTP in both circumstances (Lynch, 1998a; Murray and Lynch, 1998a,b; Foy et al., 2008b; Sterlemann et al., 2010). Results are emerging, which suggest that proteins, such as kinases, which are activated by stress, are also involved in LTP impairment associated with aging; O'Donnell et al. (2000) eloquently demonstrated that the activity of two stressinduced mitogen-activated protein kinases, c-Jun $\mathrm{NH}_{2}$-terminal kinase (JNK) and p38 are increased with advanced age which could contribute to impairment in LTP induction during senescence. Future studies are required to determine the impact of stress and aging interaction on LTP and underlying signaling cascades.

\section{LTP DURING PATHOLOGICAL CONDITIONS}

Like aging, various neurodegenerative diseases and pathological conditions influence induction of LTP and determine the degree and duration of synaptic strength. Alzheimer's disease (AD) is the most common neurodegenerative disease in the elderly population; the hippocampus is especially susceptible in $\mathrm{AD}$ and early degenerative symptoms include substantial deficits in the performance of hippocampal-dependent cognitive abilities such as spatial learning and memory. The cognitive impairments observed in $\mathrm{AD}$ patients are widely believed to be due to the progressive disruption of synaptic function and neurodegeneration triggered by aggregated amyloid- $\beta$, which is implicated in the pathogenesis of $\mathrm{AD}$ and contributes to the impairment of LTP (Cullen et al., 1997; Freir and Herron, 2003; Costello and Herron, 2004; Klyubin et al., 2004; Wang et al., 2004a,b; Costello et al., 2005; Welsby et al., 2007; Schmid et al., 2008, 2009; Shankar et al., 2008; Shipton et al., 2011). Results demonstrate that amyloid- $\beta$ specifically interacts with several major intracellular signaling pathways including the $\mathrm{Ca}^{2+}$-dependent protein phosphatase calcineurin, CaMKII, cAMP/ PKA, protein phosphatase 1, and CREB, all of which are downstream of NMDA receptor signaling and alter hippocampal LTP (Zhao et al., 2004; Knobloch et al., 2007; Wang et al., 2009; Yamin, 2009; Zeng et al., 2010). One study recently demonstrated that amyloid- $\beta$-induced impairment in LTP results from perturbed CaMKII signaling pathways but could be rescued by pretreatment with brain-derived neurotrophic factors (Zeng et al., 2010). Other results suggest that amyloid- $\beta$ closely interacts with and attenuates synaptic AMPA receptors contributing to impairments in LTP (Parameshwaran et al., 2007). Changes in LTP have been observed in several animal models of AD (Chapman et al., 1999; Jacobsen et al., 2006; Abbas et al., 2009; Auffret et al., 2009, 2010; Gengler et al., 2010; Middei et al., 2010; Ondrejcak et al., 2010; Tran et al., 2010). Review of literature suggests that a deficit in LTP induction is associated with $\mathrm{AD}$ and there is increasing evidence which suggests that impaired LTP is an event occurring early in AD pathology.

In addition to protein kinase, calcium-dependent lipases may contribute to the molecular mechanisms implicated in LTP by modulating AMPA receptors (Okada et al., 1989; Massicotte et al.,
1990, 1991; Gagne et al., 1996). Apolipoprotein E (ApoE) is synthesized predominantly by the astrocytes in the brain and plays a critical role in regulation of plasma cholesterol and participates in transport of dietary lipids (Mahley et al., 1984; Mahley, 1988); ApoE comprises three isoforms, apoE2, apoE3, and apoE4 and has been reported in the general human population with apoE4 being the most common isoform, which is genetically associated with late onset of the AD (Schmechel et al., 1993). ApoE could play a role in synaptic plasticity through lipid homeostasis. Altered cellular metabolism of ApoE knockouts contributes to the neuropathology and cognitive deficits that develop in AD. In some studies, LTP is impaired in apoE-deficient mice (Masliah et al., 1996, 1997; Krugers et al., 1997), but another study reported no significant change in LTP (Anderson et al., 1998); furthermore, one study found a significant impairment in LTP only in young but not in aged ApoE knockout mice (Valastro et al., 2001). Results demonstrate that modulation of AMPA receptor could be a possible mechanism involved in impaired LTP observed in ApoE knockouts (Valastro et al., 2001). For further readings, see Trommer et al. (2004, 2005), Yun et al. (2007), Korwek et al. (2009), Chen et al. (2010b), and Dumanis et al. (2011).

In addition to $\mathrm{AD}$, an impairment in LTP induction has been observed in several other pathological conditions, including diabetes (Biessels et al., 1996; Kamal et al., 1999, 2000, 2005; Valastro et al., 2002; Artola et al., 2005; Artola, 2008), Parkinson's disease (Bagetta et al., 2010), Fragile X Syndrome (Lauterborn et al., 2007; Connor et al., 2011), Down syndrome (Costa and Grybko, 2005; Siarey et al., 2005), Rett syndrome (Moretti et al., 2006; Weng et al., 2011), Huntington's disease (Usdin et al., 1999; Murphy et al., 2000; Lynch et al., 2007b), Niemann-Pick disease type C (Zhou et al., 2011), Rubinstein-Taybi syndrome (Alarcon et al., 2004), brain inflammation (Min et al., 2009; Lynch, 2010), glioma (Wang et al., 2010), and chronic liver failure (Monfort et al., 2007). Also, an impaired LTP has been observed following sleep deprivation (Campbell et al., 2002; Davis et al., 2003; McDermott et al., 2003; Kim et al., 2005; Ravassard et al., 2009; Aleisa et al., 2010; Alhaider et al., 2010, 2011; Poe et al., 2010; Xie et al., 2010), ethanol drinking (Randall et al., 1995; Schummers et al., 1997; Chandler, 2003; Wright et al., 2003; Stephens et al., 2005; Tokuda et al., 2007), lead exposure (Gilbert and Mack, 1998; Zhao et al., 1999), and thyroid deficiency (Dong et al., 2005; Sui et al., 2005). A review of the literature clearly demonstrates that neurodegenerative diseases, along with other pathological conditions, negatively impact induction, expression, and maintenance of LTP. However, in order to develop a therapeutic intervention to ameliorate impaired LTP, future studies should be designed to delineate the neural circuits, cellular mechanisms, and signaling pathways altered by diseases.

\section{CONCLUSION}

Copious amounts of data generated over the past 38 years have provided insight regarding the complexities of the neural basis of learning and memory. Currently, LTP in the hippocampus is the vanguard and the best documented neuronal substrate for memory formation. A wealth of information relating the molecular and cellular signaling mechanisms underlying LTP induction, expression, and maintenance, has provided a ray of hope in delineating the ways 
by which learning occurs and memories are formed. However, a full understanding of how memories are constructed and which neural circuits are responsible for acquisition, consolidation, and recall of created memories has not been accomplished. Aging, diseases, stress, and other pathological conditions adversely influence learning and memory capabilities. A plethora of information gathered over the last couple of decades demonstrates an impairment in LTP during aging, stress, and disease and is thought to contribute to a decline in learning and memory performance. However, much work is needed in order to acquire a true understanding of LTP impairment resulting from various pathological conditions. Further progress in delineating the neural and cellular bases of

\section{REFERENCES}

Abbas, T., Faivre, E., and Holscher, C. (2009). Impairment of synaptic plasticity and memory formation in GLP-1 receptor KO mice: interaction between type 2 diabetes and Alzheimer's disease. Behav. Brain Res. 205, 265-271.

Abel, T., Nguyen, P.V., Barad, M., Deuel, T. A., Kandel, E. R., and Bourtchouladze, R. (1997). Genetic demonstration of a role for PKA in the late phase of LTP and in hippocampus-based long-term memory. Cell 88, 615-626.

Abraham, W. C. (2003). How long will long-term potentiation last? Philos. Trans. R. Soc. Lond. B Biol. Sci. 358, 735-744.

Abraham, W. C., and Bear, M. F. (1996). Metaplasticity: the plasticity of synaptic plasticity. Trends Neurosci. 19, 126-130.

Abraham, W. C., Mason-Parker, S. E., Bear, M. F., Webb, S., and Tate, W. P. (2001). Heterosynaptic metaplasticity in the hippocampus in vivo: a BCM-like modifiable threshold for LTP. Proc. Natl. Acad. Sci. U.S.A. 98, 10924-10929.

Abraham, W. C., and Tate, W. P. (1997). Metaplasticity: a new vista across the field of synaptic plasticity. Prog. Neurobiol. 52, 303-323.

Abraham, W. C., and Williams, J. M. (2008). LTP maintenance and its protein synthesis-dependence. Neurobiol. Learn. Mem. 89, 260-268.

Abush, H., and Akirav, I. (2010). Cannabinoids modulate hippocampal memory and plasticity. Hippocampus 20, 1126-1138.

Aizenman, E., Hartnett, K. A., and Reynolds, I. J. (1990). Oxygen free radicals regulate NMDA receptor function via a redox modulatory site. Neuron 5, 841-846.

Aizenman, E., Lipton, S. A., and Loring, R. H. (1989). Selective modulation of NMDA responses by reduction and oxidation. Neuron 2, 1257-1263.

Akaishi, T., Nakazawa, K., Sato, K., Saito, H., Ohno, Y., and Ito, Y. (2004).
Modulation of voltage-gated Ca2+ current by 4-hydroxynonenal in dentate granule cells. Biol. Pharm. Bull. $27,174-179$

Akbari, E., Motamedi, F., Davoodi, F. G., Noorbakhshnia, M., and Ghanbarian, E. (2011). Orexin-1 receptor mediates long-term potentiation in the dentate gyrus area of freely moving rats. Behav. Brain Res. 216, 375-380.

Alarcon, J. M., Malleret, G., Touzani, K., Vronskaya, S., Ishii, S., Kandel, E. R., and Barco, A. (2004). Chromatin acetylation, memory, and LTP are impaired in $\mathrm{CBP}+/$ - mice: a model for the cognitive deficit in RubinsteinTaybi syndrome and its amelioration. Neuron 42, 947-959.

Albensi, B. C., Sullivan, P. G., Thompson, M. B., Scheff, S. W., and Mattson, M. P. (2000). Cyclosporin ameliorates traumatic brain-injury-induced alterations of hippocampal synaptic plasticity. Exp. Neurol. 162, 385-389.

Aleisa, A. M., Helal, G., Alhaider, I. A., Alzoubi, K. H., Srivareerat, M., Tran, T. T.,Al-Rejaie, S. S., and Alkadhi, K.A. (2010). Acute nicotine treatment prevents REM sleep deprivation-induced learning and memory impairment in rat. Hippocampus. doi: 10.1002/ hipo.20806. [Epub ahead of print].

Alfarez, D. N., Joels, M., and Krugers, H. J. (2003). Chronic unpredictable stress impairs long-term potentiation in rat hippocampal CA1 area and dentate gyrus in vitro. Eur. J. Neurosci. 17, 1928-1934.

Alfarez, D. N., Wiegert, O., Joels, M., and Krugers, H. J. (2002). Corticosterone and stress reduce synaptic potentiation in mouse hippocampal slices with mild stimulation. Neuroscience 115, 1119-1126.

Alhaider, I. A., Aleisa, A. M., Tran, T. T., and Alkadhi, K. A. (2011). Sleep deprivation prevents stimulation-induced increases of levels of P-CREB and BDNF: protection by caffeine. Mol. Cell. Neurosci. 46, 742-751.

Alhaider, I. A., Aleisa, A. M., Tran, T. T., Alzoubi, K. H., and Alkadhi, K. A.

impaired LTP during aging, stress, and diseases and the impact on cognitive function will require an approach that emphasizes the importance of how neural pathways and signaling mechanisms are altered.

\section{ACKNOWLEDGMENTS}

Financial support by National Institutes of Aging Grant AG014979, AG037984, AG036800 and the Evelyn F. McKnight Brain Research Foundation is highly appreciated. Special thanks to Jeffrey Thinschmidt and Thomas Foster for constructive suggestions and Clare Stokes, Gina Prado, Michael Guidi, and Linda Bean for editorial assistance.

(2010). Chronic caffeine treatment prevents sleep deprivation-induced impairment of cognitive function and synaptic plasticity. Sleep 33, 437-444.

Amaral, D. G., and Kurz, J. (1985). An analysis of the origins of the cholinergic and noncholinergic septal projections to the hippocampal formation of the rat. J. Comp. Neurol. 240,37-59.

Andersen, P., Morris, R. G., Amaral, D. G., Bliss, T. V., and O'Keefe, J. (2007). The Hippocampus Book. New York: Oxford University Press.

Andersen, P., Sundberg, S. H., Sveen, O. and Wigstrom, H. (1977). Specific long-lasting potentiation of synaptic transmission in hippocampal slices. Nature 266, 736-737.

Anderson, R., Barnes, J. C., Bliss, T. V. Cain, D. P., Cambon, K., Davies, H. A., Errington, M. L., Fellows, L.A., Gray, R. A., Hoh, T., Stewart, M., Large, C. H., and Higgins, G.A. (1998). Behavioural, physiological and morphological analysis of a line of apolipoprotein E knockout mouse. Neuroscience 85, 93-110.

Annunziato, L., Amoroso, S., Pannaccione, A., Cataldi, M., Pignataro, G., D'Alessio, A., Sirabella, R., Secondo, A., Sibaud, L., and Di Renzo, G. F. (2003). Apoptosis induced in neuronal cells by oxidative stress: role played by caspases and intracellular calcium ions. Toxicol. Lett. 139, 125-133.

Anwyl, R. (2009). Metabotropic glutamate receptor-dependent long-term potentiation. Neuropharmacology 56, 735-740.

Aou, S., Li, X. L., Li, A. J., Oomura, Y., Shiraishi, T., Sasaki, K., Imamura, T. and Wayner, M. J. (2003). Orexin-A (hypocretin-1) impairs Morris water maze performance and CA1-Schaffer collateral long-term potentiation in rats. Neuroscience 119, 1221-1228.

Arancio, O., Kiebler, M., Lee, C. J., LevRam, V., Tsien, R. Y., Kandel, E. R., and Hawkins, R. D. (1996). Nitric oxide acts directly in the presynaptic neuron to produce long-term potentiation in cultured hippocampal neurons. Cell 87, 1025-1035.
Artola, A. (2008). Diabetes-, stress- and ageing-related changes in synaptic plasticity in hippocampus and neocortex - the same metaplastic process? Eur. J. Pharmacol. 585, 153-162.

Artola, A., Kamal, A., Ramakers, G. M., Biessels, G. J., and Gispen, W. H. (2005). Diabetes mellitus concomitantly facilitates the induction of longterm depression and inhibits that of long-term potentiation in hippocampus. Eur. J. Neurosci. 22, 169-178.

Artola, A., and Singer, W. (1987). Longterm potentiation and NMDA receptors in rat visual cortex. Nature 330 , 649-652.

Artola, A., and Singer, W. (1993). Longterm depression of excitatory synaptic transmission and its relationship to long-term potentiation. Trends Neurosci. 16, 480-487.

Artola, A., von Frijtag, J. C., Fermont, P.C., Gispen, W. H., Schrama, L. H., Kamal, A., and Spruijt, B. M. (2006). Longlasting modulation of the induction of LTD and LTP in rat hippocampal CA1 by behavioural stress and environmental enrichment. Eur. J. Neurosci. 23, 261-272.

Atkins, C. M., Davare, M. A., Oh, M. C., Derkach, V., and Soderling, T. R. (2005). Bidirectional regulation of cytoplasmic polyadenylation elementbinding protein phosphorylation by Ca2+/calmodulin-dependent protein kinase II and protein phosphatase 1 during hippocampal long-term potentiation. J. Neurosci. 25, 5604-5610.

Auerbach, J. M., and Segal, M. (1997). Peroxide modulation of slow onset potentiation in rat hippocampus. $J$. Neurosci. 17, 8695-8701.

Auffret, A., Gautheron, V., Mattson, M. P., Mariani, J., and Rovira, C. (2010). Progressive age-related impairment of the late long-term potentiation in Alzheimer's disease presenilin-1 mutant knock-in mice. J. Alzheimers Dis. 19, 1021-1033.

Auffret, A., Gautheron, V., Repici, M., Kraftsik, R., Mount, H. T., Mariani, J., and Rovira, C. (2009). Age-dependent 
impairment of spine morphology and synaptic plasticity in hippocampal CA1 neurons of a presenilin 1 transgenic mouse model of Alzheimer's disease. J. Neurosci. 29, 10144-10152.

Azmitia, E. C., and Segal, M. (1978). An autoradiographic analysis of the differential ascending projections of the dorsal and median raphe nuclei in the rat. J. Comp. Neurol. 179, 641-667.

Backman, L., Nyberg, L., Lindenberger, U., Li, S. C., and Farde, L. (2006). The correlative triad among aging, dopamine, and cognition: current status and future prospects. Neurosci. Biobehav. Rev. 30, 791-807.

Bagetta, V., Ghiglieri, V., Sgobio, C., Calabresi, P., and Picconi, B. (2010). Synaptic dysfunction in Parkinson's disease. Biochem. Soc. Trans. 38, 493-497.

Barad, M., Bourtchouladze, R., Winder, D. G., Golan, H., and Kandel, E. (1998). Rolipram, a type IV-specific phosphodiesterase inhibitor, facilitates the establishment of long-lasting longterm potentiation and improves memory. Proc. Natl. Acad. Sci. U.S.A. 95, 15020-15025.

Barnes, C. A. (1979). Memory deficits associated with senescence: a neurophysiological and behavioral study in the rat. J. Comp. Physiol. Psychol. 93, 74-104.

Barnes, C. A. (1990). Effects of aging on the dynamics of information processing and synaptic weight changes in the mammalian hippocampus. Prog. Brain Res. 86, 89-104.

Barnes, C. A. (1994). Normal aging: regionally specific changes in hippocampal synaptic transmission. Trends Neurosci. 17, 13-18.

Barnes, C. A. (2003). Long-term potentiation and the ageing brain. Philos. Trans. R. Soc. Lond., B, Biol. Sci. 358, 765-772.

Barnes, C. A., Rao, G., and McNaughton, B. L. (1996). Functional integrity of NMDA-dependent LTP induction mechanisms across the lifespan of F-344 rats. Learn. Mem. 3, 124-137.

Barnes, C. A., Rao, G., and Shen, J. (1997). Age-related decrease in the N-methylD-aspartateR-mediated excitatory postsynaptic potential in hippocampal region CA1. Neurobiol. Aging 18, 445-452.

Barnes, S. J., Opitz, T., Merkens, M., Kelly, T., von der Brelie, C., Krueppel, R., and Beck, H. (2010). Stable mossy fiber long-term potentiation requires calcium influx at the granule cell soma, protein synthesis, and microtubule-dependent axonal transport. J. Neurosci. 30, 12996-13004.

Bashir, Z. I., Bortolotto, Z. A., Davies, C. H., Berretta, N., Irving, A. J., Seal, A. J., Henley, J. M., Jane, D. E., Watkins,
J. C., and Collingridge, G. L. (1993). Induction of LTP in the hippocampus needs synaptic activation of glutamate metabotropic receptors. Nature 363, 347-350.

Baudry, M., Bi, X., Gall, C., and Lynch, G. (2011). The biochemistry of memory: the 26year journey of a "new and specific hypothesis”. Neurobiol. Learn. Mem. 95, 125-133.

Bayazitov, I. T., Richardson, R. J., Fricke, R. G., and Zakharenko, S. S. (2007). Slow presynaptic and fast postsynaptic components of compound longterm potentiation. J. Neurosci. 27, 11510-11521.

Bear, M. F., and Malenka, R. C. (1994). Synaptic plasticity: LTP and LTD. Curr. Opin. Neurobiol. 4, 389-399.

Beck, H., Goussakov, I. V., Lie, A., Helmstaedter, C., and Elger, C. E. (2000). Synaptic plasticity in the human dentate gyrus. J. Neurosci. 20, 7080-7086.

Beckman, K. B., and Ames, B. N. (1998). The free radical theory of aging matures. Physiol. Rev. 78, 547-581.

Bekkers, J. M., and Stevens, C. F. (1990). Presynaptic mechanism for long-term potentiation in the hippocampus. Nature 346, 724-729.

Bernard, C. L., Hirsch, J. C., Khazipov, R., Ben-Ari, Y., and Gozlan, H. (1997). Redox modulation of synaptic responses and plasticity in rat CA1 hippocampal neurons. Exp. Brain Res. 113, 343-352.

Berridge, M. J. (1998). Neuronal calcium signaling. Neuron 21, 13-26.

Bienenstock, E. L., Cooper, L. N., and Munro, P. W. (1982). Theory for the development of neuron selectivity: orientation specificity and binocular interaction in visual cortex. J. Neurosci. 2, 32-48.

Biessels, G. J., Kamal, A., Ramakers, G. M., Urban, I. J., Spruijt, B. M., Erkelens, D. W., and Gispen, W. H. (1996). Place learning and hippocampal synaptic plasticity in streptozotocin-induced diabetic rats. Diabetes 45, 1259-1266.

Billard, J. M. (2006). Ageing, hippocampal synaptic activity and magnesium. Magnes. Res. 19, 199-215.

Billard, J. M., and Rouaud, E. (2007). Deficit of NMDA receptor activation in CA1 hippocampal area of aged rats is rescued by D-cycloserine. Eur. J. Neurosci. 25, 2260-2268.

Bland, B. H. (1986). The physiology and pharmacology of hippocampal formation theta rhythms. Prog. Neurobiol. 26, 1-54.

Blank, T., Nijholt, I., Kye, M. J., Radulovic, J., and Spiess, J. (2003). Smallconductance, Ca2+-activated $\mathrm{K}+$ channel SK3 generates age-related memory and LTP deficits. Nat. Neurosci. 6, 911-912.
Bliss, T.V., and Collingridge, G. L. (1993). A synaptic model of memory: longterm potentiation in the hippocampus. Nature 361, 31-39.

Bliss, T. V., and Gardner-Medwin, A. R. (1973). Long-lasting potentiation of synaptic transmission in the dentate area of the unanaestetized rabbit following stimulation of the perforant path. J. Physiol. (Lond.) 232, 357-374

Bliss, T. V., and Lomo, T. (1973). Longlasting potentiation of synaptic transmission in the dentate area of the anaesthetized rabbit following stimulation of the perforant path. $J$. Physiol. (Lond.) 232, 331-356.

Blitzer, R. D., Gil, O., and Landau, E. M. (1990). Cholinergic stimulation enhances long-term potentiation in the $\mathrm{CA} 1$ region of rat hippocampus. Neurosci. Lett. 119, 207-210.

Blundon, J. A., and Zakharenko, S. S. (2008). Dissecting the components of long-term potentiation. Neuroscientist 14, 598-608.

Bodhinathan, K., Kumar, A., and Foster, T. C. (2010a). Redox sensitive calcium stores underlie enhanced after hyperpolarization of aged neurons: role for ryanodine receptor mediated calcium signaling. J. Neurophysiol. 104 2586-2593.

Bodhinathan, K., Kumar, A., and Foster, T. C. (2010b). Intracellular redox state alters NMDA receptor response during aging through $\mathrm{Ca} 2+/$ calmodulindependent protein kinase II. $J$. Neurosci. 30, 1914-1924.

Bohme, G. A., Bon, C., Stutzmann, J. M., Doble, A., and Blanchard, J. C. (1991). Possible involvement of nitric oxide in long-term potentiation. Eur. J. Pharmacol. 199, 379-381.

Bolshakov, V. Y., Golan, H., Kandel, E. R., and Siegelbaum, S. A. (1997). Recruitment of new sites of synaptic transmission during the cAMPdependent late phase of LTP at CA3-CA1 synapses in the hippocampus. Neuron 19, 635-651.

Bon, C., Bohme, G. A., Doble, A. Stutzmann, J. M., and Blanchard, J. C. (1992). A role for nitric oxide in longterm potentiation. Eur. J. Neurosci. 4 , 420-424.

Boric, K., Munoz, P., Gallagher, M., and Kirkwood, A. (2008). Potential adaptive function for altered longterm potentiation mechanisms in aging hippocampus. J. Neurosci. 28, 8034-8039.

Bortolotto, Z. A., and Collingridge, G. L. (1993). Characterisation of LTP induced by the activation of glutamate metabotropic receptors in area $\mathrm{CAl}$ of the hippocampus. Neuropharmacology $32,1-9$.

Bortolotto, Z. A., Fitzjohn, S. M., and Collingridge, G. L. (1999). Roles of metabotropic glutamate receptors in LTP and LTD in the hippocampus. Curr. Opin. Neurobiol. 9, 299-304.

Bredt, D. S., and Nicoll, R. A. (2003). AMPA receptor trafficking at excitatory synapses. Neuron 40, 361-379.

Brown, R.E., Fedorov, N. B., Haas, H.L., and Reymann, K. G. (1995). Histaminergic modulation of synaptic plasticity in area CA1 of rat hippocampal slices. Neuropharmacology 34, 181-190.

Bruning, R. H., Holzbauer, E., and Kimberlin, C. (1975). Age, word imagery, and delay interval: effects on short-term and long-term retention. J. Gerontol. 30, 312-318.

Buchanan, K. A., Petrovic, M. M. Chamberlain, S. E., Marrion, N. V., and Mellor, J. R. (2010). Facilitation of long-term potentiation by muscarinic $\mathrm{M}(1)$ receptors is mediated by inhibition of SK channels. Neuron $68,948-963$.

Burke, S. N., and Barnes, C. A. (2010). Senescent synapses and hippocampal circuit dynamics. Trends Neurosci. 33, 153-161.

Cabezas, C., and Buno, W. (2011). BDNF is required for the induction of a presynaptic component of the functional conversion of silent synapses. Hippocampus 21, 374-385.

Cai, F., Wang, F., Lin, F. K., Liu, C., Ma, L. Q., Liu, J., Wu, W.N., Wang, W., Wang, J. H., and Chen, J. G. (2008). Redox modulation of long-term potentiation in the hippocampus via regulation of the glycogen synthase kinase-3beta pathway. Free Radic. Biol. Med. 45, 964-970.

Calabresi, P., Pisani, A., Mercuri, N. B., and Bernardi, G. (1992). Long-term potentiation in the striatum is unmasked by removing the voltage-dependent magnesium block of NMDA receptor channels. Eur. J. Neurosci. 4, 929-935.

Campbell, I. G., Guinan, M. J., and Horowitz, J. M. (2002). Sleep deprivation impairs long-term potentiation in rat hippocampal slices. J. Neurophysiol. 88, 1073-1076.

Canas, P. M., Duarte, J. M., Rodrigues, R. J., Kofalvi, A., and Cunha, R. A. (2009). Modification upon aging of the density of presynaptic modulation systems in the hippocampus. Neurobiol. Aging 30, 1877-1884.

Carlini, V. P., Perez, M. F., Salde, E., Schioth, H. B., Ramirez, O. A., and de Barioglio, S. R. (2010). Ghrelin induced memory facilitation implicates nitric oxide synthase activation and decrease in the threshold to promote LTP in hippocampal dentate gyrus. Physiol. Behav. 101, 117-123.

Carlson, G., Wang, Y., and Alger, B. E. (2002). Endocannabinoids facilitate the induction of LTP in the hippocampus. Nat. Neurosci. 5, 723-724. 
Cavus, I., and Teyler, T. (1996). Two forms of long-term potentiation in area CA1 activate different signal transduction cascades. J. Neurophysiol. 76, 3038-3047.

Chandler, L. J. (2003). Ethanol and brain plasticity: receptors and molecular networks of the postsynaptic density as targets of ethanol. Pharmacol. Ther. 99, 311-326.

Chapman, P. F., White, G. L., Jones, M. W., Cooper-Blacketer, D., Marshall, V. J., Irizarry, M., Younkin, L., Good, M. A., Bliss, T. V., Hyman, B. T., Younkin, S. G., and Hsiao, K. K. (1999). Impaired synaptic plasticity and learning in aged amyloid precursor protein transgenic mice. Nat. Neurosci. 2, 271-276.

Charpier, S., and Deniau, J. M. (1997). In vivo activity-dependent plasticity at cortico-striatal connections: evidence for physiological long-term potentiation. Proc. Natl. Acad. Sci. U.S.A. 94, 7036-7040.

Chen, C. C., Yang, C. H., Huang, C. C., and Hsu, K.S. (2010a). Acute stress impairs hippocampal mossy fiber-CA3 longterm potentiation by enhancing cAMP-specific phosphodiesterase 4 activity. Neuropsychopharmacology 35, 1605-1617.

Chen, Y., Durakoglugil, M. S., Xian, X., and Herz, J. (2010b). ApoE4 reduces glutamate receptor function and synaptic plasticity by selectively impairing ApoE receptor recycling. Proc. Natl. Acad. Sci. U.S.A. 107, 12011-12016.

Chen, P. E., Geballe, M. T., Stansfeld, P. J., Johnston, A. R., Yuan, H., Jacob, A. L., Snyder, J. P., Traynelis, S. F., and Wyllie, D. J. (2005). Structural features of the glutamate binding site in recombinant NR1/NR2A N-methyl-D-aspartate receptors determined by site-directed mutagenesis and molecular modeling. Mol. Pharmacol. 67, 1470-1484.

Chen, W. R., Lee, S., Kato, K., Spencer, D. D., Shepherd, G. M., and Williamson, A. (1996). Long-term modifications of synaptic efficacy in the human inferior and middle temporal cortex. Proc. Natl. Acad. Sci. U.S.A. 93, 8011-8015.

Chetkovich, D. M., Gray, R., Johnston, D., and Sweatt, J.D. (1991). N-methyl-Daspartate receptor activation increases cAMP levels and voltage-gated $\mathrm{Ca} 2+$ channel activity in area CA1 of hippocampus. Proc. Natl. Acad. Sci. U.S.A. 88, 6467-6471.

Chetkovich, D. M., and Sweatt, J. D. (1993). nMDA receptor activation increases cyclic AMP in area CAl of the hippocampus via calcium/calmodulin stimulation of adenylyl cyclase. J. Neurochem. 61, 1933-1942.

Chevaleyre, V., and Castillo, P. E. (2004). Endocannabinoid-mediated metaplasticity in the hippocampus. Neuron $43,871-881$.
Chevaleyre, V., Heifets, B. D., Kaeser, P. S., Sudhof, T. C., and Castillo, P.E. (2007). Endocannabinoid-mediated longterm plasticity requires cAMP/PKA signaling and RIMlalpha. Neuron 54, 801-812.

Chevaleyre, V., Takahashi, K. A., and Castillo, P. E. (2006). Endocannabinoid-mediated synaptic plasticity in the CNS. Annu. Rev. Neurosci. 29, 37-76.

Choi, Y., Chen, H. V., and Lipton, S. A. (2001). Three pairs of cysteine residues mediate both redox and $\mathrm{zn} 2+$ modulation of the nmda receptor. J. Neurosci. 21, 392-400.

Choi, Y. B., and Lipton, S. A. (2000). Redox modulation of the NMDA receptor. Cell. Mol. Life Sci. 57, 1535-1541.

Christie, B. R., Magee, J. C., and Johnston, D. (1996). The role of dendritic action potentials and $\mathrm{Ca} 2+$ influx in the induction of homosynaptic longterm depression in hippocampal CA1 pyramidal neurons. Learn. Mem. 3, 160-169.

Christie, B. R., Schexnayder, L. K., and Johnston, D. (1997). Contribution of voltage-gated Ca2+ channels to homosynaptic long-term depression in the CA1 region in vitro. J. Neurophysiol. 77, 1651-1655.

Clarke, R. M., Lyons, A., O'Connell, F., Deighan, B. F., Barry, C. E., Anyakoha, N. G., Nicolaou, A., and Lynch, M. A. (2008). A pivotal role for interleukin-4 in atorvastatin-associated neuroprotection in rat brain. J. Biol. Chem. 283, 1808-1817.

Clugnet, M. C., and LeDoux, J. E. (1990). Synaptic plasticity in fear conditioning circuits: induction of LTP in the lateral nucleus of the amygdala by stimulation of the medial geniculate body. $J$. Neurosci. 10, 2818-2824.

Cohen, A. S., Coussens, C. M., Raymond, C. R., and Abraham, W. C. (1999). Long-lasting increase in cellular excitability associated with the priming of LTP induction in rat hippocampus. $J$. Neurophysiol. 82, 3139-3148.

Collingridge, G. L., and Bliss, T. V. (1995). Memories of NMDA receptors and LTP. Trends Neurosci. 18, 54-56.

Collingridge, G. L., Kehl, S. J., and McLennan, H. (1983). Excitatory amino acids in synaptic transmission in the Schaffer collateral-commissural pathway of the rat hippocampus. $J$. Physiol. (Lond.) 334, 33-46.

Connor, S. A., Hoeffer, C. A., Klann, E., and Nguyen, P. V. (2011). Fragile X mental retardation protein regulates heterosynaptic plasticity in the hippocampus. Learn. Mem. 18, 207-220.

Cooke, S. F., and Bliss, T. V. (2006). Plasticity in the human central nervous system. Brain 129, 1659-1673.
Cooper, J., Roth, R., and Bloom, F. (2003). The Biochemical Basis of Neuropharmacology. New York: Oxford University Press.

Cordoba-Montoya, D. A., Albert, J., and Lopez-Martin, S. (2010). All together now: long term potentiation in the human cortex. Rev Neurol51,367-374.

Costa, A. C., and Grybko, M. J. (2005). Deficits in hippocampal CA1 LTP induced by TBS but not HFS in the Ts65Dn mouse: a model of Down syndrome. Neurosci. Lett. 382 , 317-322.

Costello, D. A., and Herron, C. E. (2004). The role of $\mathrm{c}$-Jun $\mathrm{N}$-terminal kinase in the A beta-mediated impairment of LTP and regulation of synaptic transmission in the hippocampus. Neuropharmacology 46, 655-662.

Costello, D.A., O'Leary, D. M., and Herron, C. E. (2005). Agonists of peroxisome proliferator-activated receptor-gamma attenuate the Abeta-mediated impairment of LTP in the hippocampus in vitro. Neuropharmacology49,359-366.

Costenla, A. R., Cunha, R. A., and de Mendonca, A. (2010). Caffeine, adenosine receptors, and synaptic plasticity. J. Alzheimers Dis. 20 (Suppl. 1), S25-S34.

Costenla, A. R., de Mendonca, A., and Ribeiro, J. A. (1999). Adenosine modulates synaptic plasticity in hippocampal slices from aged rats. Brain Res. 851, 228-234.

Cowley, T. R., O'Sullivan, J., Blau, C., Deighan, B. F., Jones, R., Kerskens, C., Richardson, J. C., Virley, D., Upton, N., and Lynch, M. A. (2011). Rosiglitazone attenuates the age-related changes in astrocytosis and the deficit in LTP. Neurobiol. Aging. doi:10.1016/j.neurobiolaging.2010.02.002. [Epub ahead of print].

Cullen, W. K., Suh, Y. H., Anwyl, R., and Rowan, M. J. (1997). Block of LTP in rat hippocampus in vivo by betaamyloid precursor protein fragments. Neuroreport 8, 3213-3217.

Davis, C. J., Harding, J. W., and Wright, J. W. (2003). REM sleep deprivationinduced deficits in the latency-to-peak induction and maintenance of longterm potentiation within the CA1 region of the hippocampus. Brain Res. 973, 293-297.

Davis, S., Markowska, A. L., Wenk, G. L. and Barnes, C. A. (1993). Acetyl-Lcarnitine: behavioral, electrophysiological, and neurochemical effects. Neurobiol. Aging 14, 107-115.

de Kloet, E. R., Karst, H., and Joels, M. (2008). Corticosteroid hormones in the central stress response: quickand-slow. Front. Neuroendocrinol. 29 268-272.

de Kloet, E. R., Oitzl, M. S., and Joels, M. (1999). Stress and cognition: are corticosteroids good or bad guys? Trends Neurosci. 22, 422-426.

de Toledo-Morrell, L., and Morrell, F. (1985). Electrophysiological markers of aging and memory loss in rats. Ann. N. Y. Acad. Sci. 444, 296-311.

Debanne, D., Gahwiler, B. H., and Thompson, S.M. (1997). Bidirectional associative plasticity of unitary CA3-CA1 EPSPs in the rat hippocampus in vitro. J. Neurophysiol. 77, 2851-2855.

Deupree, D. L., Bradley, J., and Turner, D. A. (1993). Age-related alterations in potentiation in the CA1 region in F344 rats. Neurobiol. Aging 14, 249-258.

Diamond, D. M., Bennett, M. C., Engstrom, D. A., Fleshner, M., and Rose, G. M. (1989). Adrenalectomy reduces the threshold for hippocampal primed burst potentiation in the anesthetized rat. Brain Res. 492, 356-360.

Diamond, D. M., Bennett, M.C., Fleshner, M., and Rose, G.M. (1992). Inverted-U relationship between the level of peripheral corticosterone and the magnitude of hippocampal primed burst potentiation. Hippocampus 2 , 421-430.

Diamond, D. M., Fleshner, M., and Rose, G. M. (1994). Psychological stress repeatedly blocks hippocampal primed burst potentiation in behaving rats. Behav. Brain Res. 62, 1-9.

Diamond, D. M., Park, C. R., Campbell, A. M., and Woodson, J. C. (2005) Competitive interactions between endogenous LTD and LTP in the hippocampus underlie the storage of emotional memories and stressinduced amnesia. Hippocampus 15, 1006-1025.

Diamond, D. M., and Rose, G. M. (1994). Stress impairs LTP and hippocampaldependent memory. Ann. N. Y. Acad. Sci. 746, 411-414.

Diana, G., Scotti de Carolis, A., Frank, C., Domenici, M. R., and Sagratella, S. (1994a). Selective reduction of hippocampal dentate frequency potentiation in aged rats with impaired place learning. Brain Res. Bull. 35, 107-111.

Diana, G., Domenici, M. R., Loizzo, A., Scotti de Carolis, A., and Sagratella, S. (1994b). Age and strain differences in rat place learning and hippocampal dentate gyrus frequency-potentiation. Neurosci. Lett. 171, 113-116.

Dias, R. B., Ribeiro, J. A., and Sebastiao, A. M. (2011). Enhancement of AMPA currentsand GluR1 membrane expression through PKA-coupled adenosine $\mathrm{A}(2 \mathrm{~A})$ receptors. Hippocampus. doi: 10.1002/hipo.20894. [Epub ahead of print].

Diez-Guerra, F. J. (2010). Neurogranin, a link between calcium/calmodulin and protein kinase $C$ signaling in synaptic plasticity. IUBMB Life 62, 597-606. 
Dingledine, R., Borges, K., Bowie, D., and Traynelis, S. F. (1999). The glutamate receptor ion channels. Pharmacol. Rev. 51, 7-61.

Disterhoft, J.F., Kronforst-Collins, M., Oh, M. M., Power, J. M., Preston, A. R., and Weiss, C. (1999). Cholinergic facilitation of trace eyeblink conditioning in aging rabbits. Life Sci. 64, 541-548.

Disterhoft, J. F., and Matthew Oh, M. (2003). Modulation of cholinergic transmission enhances excitability of hippocampal pyramidal neurons and ameliorates learning impairments in aging animals. Neurobiol. Learn. Mem. $80,223-233$.

Disterhoft, J. F., Moyer, J, R., and Thompson, L. T. (1994). The calcium rationale in aging and Alzheimer's disease. Evidence from an animal model of normal aging. Ann. N. Y. Acad. Sci. 747, 382-406.

Disterhoft, J. F., and Oh, M. M. (2006). Learning, aging and intrinsic neuronal plasticity. Trends Neurosci. 29, 587-599.

Disterhoft, J. F., Thompson, L. T., Moyer, J. R., and Mogul, D. J. (1996). Calciumdependent afterhyperpolarization and learning in young and aging hippocampus. Life Sci. 59, 413-420.

Dong, J., Yin, H., Liu, W., Wang, P., Jiang, Y., and Chen, J. (2005). Congenital iodine deficiency and hypothyroidism impair LTP and decrease C-fos and C-jun expression in rat hippocampus. Neurotoxicology 26, 417-426.

Dong, Z., Zhong, W., Tian, M., Han, H., Cao, J., Xu, T., Luo, J., and $\mathrm{Xu}, \mathrm{L}$. (2006). Stress evoked by opiate withdrawal facilitates hippocampal LTP in vivo. Hippocampus 16, 1017-1025.

Doralp, S., and Leung, L. S. (2008). Cholinergic modulation of hippocampal CA1 basal-dendritic long-term potentiation. Neurobiol. Learn. Mem. 90, 382-388.

Douglas, R. M., and Goddard, G. V. (1975). Long-term potentiation of the perforant path-granule cell synapse in the rat hippocampus. Brain Res. 86, 205-215.

Dumanis, S. B., Cha, H. J., Song, J. M., Trotter, J. H., Spitzer, M., Lee, J. Y., Weeber, E. J., Turner, R. S., Pak, D. T., Rebeck, G. W., and Hoe, H. S. (2011). ApoE receptor 2 regulates synapse and dendritic spine formation. PLoS ONE 6, e17203. doi: 10.1371/journal. pone. 0017203

Duzel, E., Bunzeck, N., Guitart-Masip, M., and Duzel, S. (2010). NOveltyrelated motivation of anticipation and exploration by dopamine (NOMAD): implications for healthy aging. Neurosci. Biobehav. Rev. 34, 660-669.

Emptage, N.J., Reid, C.A., Fine,A., and Bliss, T. V. (2003). Optical quantal analysis reveals a presynaptic component of LTP at hippocampal Schaffer-associational synapses. Neuron $38,797-804$.

Feldman, D. E. (2009). Synaptic mechanisms for plasticity in neocortex. Annu. Rev. Neurosci. 32, 33-55.

Fernandez de Sevilla, D., and Buno, W. (2010). The muscarinic longterm enhancement of NMDA and AMPA receptor-mediated transmission at schaffer collateral synapses develop through different intracellular mechanisms. J. Neurosci. 30, 11032-11042.

Fernandez de Sevilla, D., Nunez,A., Borde, M., Malinow, R., and Buno, W. (2008). Cholinergic-mediated IP3-receptor activation induces long-lasting synaptic enhancement in CAl pyramidal neurons. J. Neurosci. 28, 1469-1478.

Fontinha, B. M., Diogenes, M. J., Ribeiro, J. A., and Sebastiao, A. M. (2008). Enhancement of long-term potentiation by brain-derived neurotrophic factor requires adenosine A2A receptor activation by endogenous adenosine. Neuropharmacology 54,924-933.

Foster, T. C. (1999). Involvement of hippocampal synaptic plasticity in agerelated memory decline. Brain Res. Rev. 30, 236-249.

Foster, T. C. (2002). Regulation of synaptic plasticity in memory and memory decline with aging. Prog. Brain Res. 138, 283-303.

Foster, T. C. (2006). Biological markers of age-related memory deficits: treatment of senescent physiology. CNS Drugs 20, 153-166.

Foster, T.C. (2007). Calcium homeostasis and modulation of synaptic plasticity in the aged brain. Aging Cell 6, 319-325.

Foster, T. C., and Kumar, A. (2002). Calcium dysregulation in the aging brain. Neuroscientist 8, 297-301.

Foster, T. C., and Kumar, A. (2007). Susceptibility to induction of longterm depression is associated with impaired memory in aged Fischer 344 rats. Neurobiol. Learn. Mem. 87, 522-535.

Foster, T. C., and Norris, C. M. (1997). Age-associated changes in Ca2+dependent processes: relation to hippocampal synaptic plasticity. Hippocampus 7, 602-612.

Foster, T. C., Sharrow, K. M., Masse, J. R., Norris, C. M., and Kumar, A. (2001). Calcineurin links $\mathrm{Ca} 2+$ dysregulation with brain aging. J. Neurosci. 21, 4066-4073.

Fox, K. (2002). Anatomical pathways and molecular mechanisms for plasticity in the barrel cortex. Neuroscience 111, 799-814.

Foy, M. R. (2001). 17beta-estradiol: effect on CA1 hippocampal synaptic plasticity. Neurobiol. Learn. Mem. 76, 239-252.
Foy, M. R. (2011). Ovarian hormones, aging and stress on hippocampal synaptic plasticity. Neurobiol. Learn. Mem. 95, 134-144.

Foy, M. R., Akopian, G., and Thompson, R. F. (2008a). Progesterone regulation of synaptic transmission and plasticity in rodent hippocampus. Learn. Mem. $15,820-822$.

Foy, M. R., Baudry, M., Foy, J. G., and Thompson, R. F. (2008b). 17betaestradiol modifies stress-induced and age-related changes in hippocampal synaptic plasticity. Behav. Neurosci. 122, 301-309.

Foy, M. R., Baudry, M., Diaz Brinton, R., and Thompson, R. F. (2008c). Estrogen and hippocampal plasticity in rodent models. J. Alzheimers Dis. 15, 589-603.

Foy, M. R., Stanton, M. E., Levine, S., and Thompson, R. F. (1987). Behavioral stress impairs long-term potentiation in rodent hippocampus. Behav. Neural Biol. 48, 138-149.

Foy, M. R., Xu, J., Xie, X., Brinton, R. D., Thompson, R. F., and Berger, T. W. (1999). 17beta-estradiol enhances NMDA receptor-mediated EPSPs and long-term potentiation. $J$. Neurophysiol. 81, 925-929.

Freir, D. B., and Herron, C. E. (2003). Nicotine enhances the depressive actions of A beta 1-40 on long-term potentiation in the rat hippocampal CA1 region in vivo. J. Neurophysiol. 89, 2917-2922.

Frey, U., Huang, Y. Y., and Kandel, E. R. (1993). Effects of cAMP simulate a late stage of LTP in hippocampal CA1 neurons. Science 260, 1661-1664.

Frey, U., Krug, M., Reymann, K. G., and Matthies, H. (1988). Anisomycin, an inhibitor of protein synthesis, blocks late phases of LTP phenomena in the hippocampal CA1 region in vitro. Brain Res. 452, 57-65.

Frey, U., and Morris, R. G. (1997). Synaptic tagging and long-term potentiation. Nature 385, 533-536.

Froemke, R. C., Poo, M. M., and Dan, Y. (2005). Spike-timing-dependent synaptic plasticity depends on dendritic location. Nature 434, 221-225.

Frotscher, M., and Leranth, C. (1985). Cholinergic innervation of the rat hippocampus as revealed by choline acetyltransferase immunocytochemistry: a combined light and electron microscopic study. J. Comp. Neurol. 239, 237-246.

Fuenzalida, M., Fernandez de Sevilla, D., and Buno, W. (2007). Changes of the EPSP waveform regulate the temporal window for spike-timing-dependent plasticity. J.Neurosci. 27, 11940-11948.

Fujii, S. (2004). ATP- and adenosinemediated signaling in the central nervous system: the role of extracellular ATP in hippocampal long-term potentiation. J. Pharmacol. Sci. 94, 103-106.

Gagne, J., Giguere, C., Tocco, G., Ohayon, M., Thompson, R. F., Baudry, M., and Massicotte, G. (1996). Effect of phosphatidylserine on the binding properties of glutamate receptors in brain sections from adult and neonatal rats. Brain Res. 740, 337-345.

Garaschuk, O., Schneggenburger, R., Schirra, C., Tempia, F., and Konnerth, A. (1996). Fractional Ca2+ currents through somatic and dendritic glutamate receptor channels of rat hippocampal CA1 pyramidal neurones. J. Physiol. (Lond.) 491(Pt 3), 757-772.

Garcia, R., Musleh, W., Tocco, G., Thompson, R. F., and Baudry, M. (1997). Time-dependent blockade of STP and LTP in hippocampal slices following acute stress in mice. Neurosci. Lett. 233, 41-44.

Gasbarri, A., Packard, M. G., Campana, E., and Pacitti, C. (1994a). Anterograde and retrograde tracing of projections from the ventral tegmental area to the hippocampal formation in the rat. Brain Res. Bull. 33, 445-452.

Gasbarri, A., Verney, C., Innocenzi, R., Campana, E., and Pacitti, C. (1994b). Mesolimbic dopaminergic neurons innervating the hippocampal formation in the rat: a combined retrograde tracing and immunohistochemical study. Brain Res. 668, 71-79.

Gaykema, R. P., Luiten, P. G., Nyakas, C., and Traber, J. (1990). Cortical projection patterns of the medial septumdiagonal band complex. J. Comp. Neurol. 293, 103-124.

Geiger, J. R., Melcher, T., Koh, D. S., Sakmann, B., Seeburg, P. H., Jonas, P., and Monyer, H. (1995). Relative abundance of subunit mRNAs determines gating and $\mathrm{Ca} 2+$ permeability of AMPA receptors in principal neurons and interneurons in rat CNS. Neuron 15, 193-204.

Gengler, S., Hamilton, A., and Holscher, C. (2010). Synaptic plasticity in the hippocampus of a APP/PS1 mouse model of Alzheimer's disease is impaired in old but not young mice. PLoS ONE 5, e9764. doi: 10.1371/journal. pone.0009764

Gerges, N. Z., Alzoubi, K. H., Park, C. R., Diamond, D. M., and Alkadhi, K. A. (2004). Adverse effect of the combination of hypothyroidism and chronic psychosocial stress on hippocampusdependent memory in rats. Behav. Brain Res. 155, 77-84.

Gerges, N. Z., Stringer, J. L., and Alkadhi, K. A. (2001). Combination of hypothyroidism and stress abolishes early LTP in the CA1 but not dentate gyrus of hippocampus of adult rats. Brain Res. 922, 250-260. 
Ghosh, A., Ginty, D. D., Bading, H., and Greenberg, M. E. (1994). Calcium regulation of gene expression in neuronal cells. J. Neurobiol. 25, 294-303.

Giambra, L. M., and Arenberg, D. (1993). Adult age differences in forgetting sentences. Psychol. Aging 8, 451-462.

Gibson, G. E., and Peterson, C. (1987). Calcium and the aging nervous system. Neurobiol. Aging 8, 329-343.

Gilbert, M. E., and Mack, C. M. (1998). Chronic lead exposure accelerates decay of long-term potentiation in rat dentate gyrus in vivo. Brain Res. 789, 139-149.

Goldsmith, S. K., and Joyce, J. N. (1994). Dopamine D2 receptor expression in hippocampus and parahippocampal cortex of rat, cat, and human in relation to tyrosine hydroxylase-immunoreactive fibers. Hippocampus 4, 354-373.

Gong, L., Gao, T. M., Huang, H., and Tong, Z. (2000). Redox modulation of large conductance calcium-activated potassium channels in CAl pyramidal neurons from adult rat hippocampus. Neurosci. Lett. 286, 191-194.

Gong, L. W., Gao, T. M., Huang, H., Zhou, K. X., and Tong, Z. (2002). ATP modulation of large conductance $\mathrm{Ca}(2+)$-activated $\mathrm{K}(+)$ channels via a functionally associated protein kinase A in CA1 pyramidal neurons from rat hippocampus. Brain Res. 951, 130-134.

Gottschalk,W., Pozzo-Miller,L.D., Figurov, A., and Lu, B. (1998). Presynaptic modulation of synaptic transmission and plasticity by brain-derived neurotrophic factor in the developing hippocampus. J. Neurosci. 18, 6830-6839.

Gozlan, H., Khazipov, R., Diabira, D., and Ben-Ari, Y. (1995). In CA1 hippocampal neurons, the redox state of NMDA receptors determines LTP expressed by NMDA but not by AMPA receptors. J. Neurophysiol. 73, 2612-2617.

Griffin, R., Nally, R., Nolan, Y., McCartney, Y., Linden, J., and Lynch, M.A. (2006). The age-related attenuation in longterm potentiation is associated with microglial activation. J. Neurochem. 99, 1263-1272.

Grover, L. M. (1998). Evidence for postsynaptic induction and expression of NMDA receptor independent LTP. J. Neurophysiol. 79, 1167-1182.

Grover, L. M., and Teyler, T. J. (1990). Two components of long-term potentiation induced by different patterns of afferent activation. Nature 347, 477-479.

Grover, L. M., and Teyler, T. J. (1992). $\mathrm{N}$-methyl-D-aspartate receptor-independent long-term potentiation in area CAl of rat hippocampus: input-specific induction and preclusion in a non-tetanized pathway. Neuroscience 49, 7-11.

Habib, D., and Dringenberg, H. C. (2009). Alternating low frequency stimulation of medial septal and commissural fibers induces NMDA-dependent, long-lasting potentiation of hippocampal synapses in urethane-anesthetized rats. Hippocampus 19, 299-307.

Habib, D., and Dringenberg, H. C. (2010). Low-frequency-induced synaptic potentiation: a paradigm shift in the field of memory-related plasticity mechanisms? Hippocampus 20, 29-35.

Haettig, J., Stefanko, D. P., Multani, M. L., Figueroa, D. X., McQuown, S. C., and Wood, M.A. (2011).HDAC inhibition modulates hippocampus-dependent long-term memory for object location in a CBP-dependent manner. Learn. Mem. 18, 71-79.

Harman, D. (1956). Aging: a theory based on free radical and radiation chemistry. J. Gerontol. 11, 298-300.

Harris, E. W., and Cotman, C. W. (1986). Long-term potentiation of guinea pig mossy fiber responses is not blocked by $\mathrm{N}$-methyl $\mathrm{D}$-aspartate antagonists. Neurosci. Lett. 70, 132-137.

Harris, E. W., Ganong, A. H., and Cotman, C.W. (1984). Long-term potentiation in the hippocampus involves activation of N-methyl-D-aspartate receptors. Brain Res. 323, 132-137.

Head, D., Rodrigue, K. M., Kennedy, K.M., and Raz, N. (2008). Neuroanatomical and cognitive mediators of age-related differences in episodic memory. Neuropsychology 22, 491-507.

Hsu, K. S., Huang, C. C., Liang, Y. C., Wu, H. M., Chen, Y. L., Lo, S. W., and Ho, W. C. (2002). Alterations in the balance of protein kinase and phosphatase activities and age-related impairments of synaptic transmission and long-term potentiation. Hippocampus 12,787-802.

Huang, Y. Y., and Kandel, E. R. (2007). Low-frequency stimulation induces a pathway-specific late phase of LTP in the amygdala that is mediated by PKA and dependent on protein synthesis. Learn. Mem. 14, 497-503.

Huang, Y. Y., Nguyen, P. V., Abel, T., and Kandel, E. R. (1996). Long-lasting forms of synaptic potentiation in the mammalian hippocampus. Learn. Mem. 3, 74-85.

Huang, Y. Y., Zakharenko, S. S., Schoch, S., Kaeser, P. S., Janz, R., Sudhof, T. C., Siegelbaum, S. A., and Kandel, E. R. (2005). Genetic evidence for a proteinkinase-A-mediated presynaptic component in NMDA-receptor-dependent forms of long-term synaptic potentiation. Proc. Natl. Acad. Sci. U.S.A. 102, 9365-9370.

Hui, Z., Guang-Yu, M., Chong-Tao, X., Quan, Y., and Xiao-Hu, X. (2005). Phenytoin reverses the chronic stressinduced impairment of memory consolidation for water maze training and depression of LTP in rat hippocampal CA1 region, but does not affect motor activity. Brain Res. Cogn. Brain Res. 24, 380-385.

Hulicka, I. M., and Rust, L. D. (1964) Age-related retention deficit as a function of learning. J Am Geriatr Soc 12, 1061-1065.

Impey, S., Mark, M., Villacres, E. C., Poser, S., Chavkin, C., and Storm, D. R. (1996). Induction of CRE-mediated gene expression by stimuli that generate long-lasting LTP in area CAl of the hippocampus. Neuron 16, 973-982.

Inoue, M., Kishimoto, A., Takai, Y., and Nishizuka, Y. (1977). Studies on a cyclic nucleotide-independent protein kinase and its proenzyme in mammalian tissues. II. Proenzyme and its activation by calcium-dependent protease from rat brain. J. Biol. Chem. 252,7610-7616.

Isaac, J. T., Nicoll, R. A., and Malenka, R. C. (1995). Evidence for silent synapses: implications for the expression of LTP. Neuron 15, 427-434.

Ivy, A. S., Rex, C. S., Chen, Y., Dube, C., Maras, P.M., Grigoriadis, D. E., Gall, C. M., Lynch, G., and Baram, T.Z. (2010). Hippocampal dysfunction and cognitive impairments provoked by chronic early-life stress involve excessive activation of CRH receptors. J. Neurosci. 30, 13005-13015.

Izumi,Y.,Clifford,D. B., and Zorumski,C.F. (1992). Inhibition of long-term potentiation by NMDA-mediated nitric oxide release. Science 257, 1273-1276.

Izumi, Y., Tokuda, K., and Zorumski, C. F. (2008). Long-term potentiation inhibition by low-level N-methyl-Daspartate receptor activation involves calcineurin, nitric oxide, and p38 mitogen-activated protein kinase. Hippocampus 18, 258-265.

Jacobsen, J. S., Wu, C. C., Redwine, J. M., Comery, T. A., Arias, R., Bowlby, M., Martone, R., Morrison, J.H., Pangalos, M. N., Reinhart, P. H., and Bloom, F. E. (2006). Early-onset behavioral and synaptic deficits in a mouse model of Alzheimer's disease. Proc. Natl. Acad. Sci. U.S.A. 103, 5161-5166.

Jaffe, D. B., Fisher, S. A., and Brown, T. H. (1994). Confocal laser scanning microscopy reveals voltage-gated calcium signals within hippocampal dendritic spines. J. Neurobiol. 25, 220-233.

Jahr, C. E., and Stevens, C. F. (1993). Calcium permeability of the N-methylD-aspartate receptor channel in hippocampal neurons in culture. Proc. Natl.Acad. Sci. U.S.A.90, 11573-11577.

Joels, M. (2001). Corticosteroid actions in the hippocampus. J. Neuroendocrinol. 13, 657-669.

Joels, M. (2006). Corticosteroid effects in the brain: u-shape it. Trends Pharmacol. Sci. 27, 244-250.

Joels, M., and Krugers, H. J. (2007). LTP after stress: up or down? Neural Plast. $2007,93202$.
Johnston, D., Christie, B. R., Frick, A. Gray, R., Hoffman, D.A., Schexnayder, L. K., Watanabe, S., and Yuan, L. L. (2003). Active dendrites, potassium channels and synaptic plasticity. Philos. Trans. R. Soc. Lond. B Biol. Sci. 358, 667-674.

Johnston, D., Fisher, R., and Gray, R. (1992). Voltage-gated calcium channels in adult hippocampal neurons. Ion Channels 3, 39-62.

Johnston, D., Hoffman, D. A., Magee, J. C., Poolos, N. P., Watanabe, S., Colbert, C. M., and Migliore, M. (2000). Dendritic potassium channels in hippocampal pyramidal neurons. J. Physiol. (Lond.) 525(Pt 1), 75-81.

Jung, M. W., Larson, J., and Lynch, G. (1990). Long-term potentiation of monosynaptic EPSPs in rat piriform cortex in vitro. Synapse 6, 279-283.

Jung, S. C., Eun, S. Y., Kim, J., and Hoffman, D.A. (2011). Kv4.2 block of long-term potentiation is partially dependent on synaptic NMDA receptor remodeling. Brain Res. Bull. 84, 17-21.

Jung, S. C., Kim, J., and Hoffman, D. A. (2008). Rapid, bidirectional remodeling of synaptic NMDA receptor subunit composition by A-type $\mathrm{K}+$ channel activity in hippocampal CA1 pyramidal neurons. Neuron 60, 657-671.

Kamal, A., Biessels, G. J., Duis, S. E., and Gispen, W. H. (2000). Learning and hippocampal synaptic plasticity in streptozotocin-diabetic rats: interaction of diabetes and ageing. Diabetologia 43, 500-506.

Kamal, A., Biessels, G. J., Ramakers, G. M., and Hendrik Gispen, W. (2005). The effect of short duration streptozotocin-induced diabetes mellitus on the late phase and threshold of longterm potentiation induction in the rat. Brain Res. 1053, 126-130.

Kamal, A., Biessels, G. J., Urban, I. J., and Gispen,W.H.(1999).Hippocampal synaptic plasticity in streptozotocin-diabetic rats: impairment of long-term potentiation and facilitation of long-term depression. Neuroscience 90, 737-745.

Kamal, A., Van der Harst, J. E., Kapteijn, C. M., Baars, A. J., Spruijt, B. M., and Ramakers, G. M. (2010). Announced reward counteracts the effects of chronic social stress on anticipatory behavior and hippocampal synaptic plasticity in rats. Exp. Brain Res. 201, 641-651.

Kamsler, A., and Segal, M. (2003). Hydrogen peroxide modulation of synaptic plasticity. J. Neurosci. 23, 269-276.

Kamsler, A., and Segal, M. (2004). Hydrogen peroxide as a diffusible signal molecule in synaptic plasticity. Mol. Neurobiol. 29, 167-178.

Kang, H. J., and Schuman, E. M. (1995). Neurotrophin-induced modulation of 
synaptic transmission in the adult hippocampus. J. Physiol. Paris 89, 11-22.

Karst, H., Berger, S., Turiault, M., Tronche, F., Schutz, G., and Joels, M. (2005). Mineralocorticoid receptors are indispensable for nongenomic modulation of hippocampal glutamate transmission by corticosterone. Proc. Natl. Acad. Sci. U.S.A. 102, 19204-19207.

Karst, H., and Joels, M. (2005). Corticosterone slowly enhances miniature excitatory postsynaptic current amplitude in mice CA1 hippocampal cells. J. Neurophysiol. 94, 3479-3486.

Kavushansky, A., Vouimba, R. M., Cohen, H., and Richter-Levin, G. (2006). Activity and plasticity in the CAl, the dentate gyrus, and the amygdala following controllable vs. uncontrollable water stress. Hippocampus 16, 35-42.

Kelleher, R. J. III, Govindarajan, A., and Tonegawa,S. (2004). Translational regulatory mechanisms in persistent forms of synaptic plasticity. Neuron 44,59-73.

Kelly, E. E., Horgan, C. P., McCaffrey, M. W., and Young, P. (2011a). The role of endosomal-recycling in long-term potentiation. Cell. Mol. Life Sci. 68, 185-194.

Kelly, L., Grehan, B., Chiesa, A. D., O'Mara, S. M., Downer, E., Sahyoun, G., Massey, K. A., Nicolaou, A., and Lynch, M. A. (2011b). The polyunsaturated fatty acids, EPA and DPA exert a protective effect in the hippocampus of the aged rat. Neurobiol. Aging. doi:10.1016/j. neurobiolaging.2010.04.001. [Epub ahead of print].

Kerchner, G. A., and Nicoll, R. A. (2008). Silent synapses and the emergence of a postsynaptic mechanism for LTP. Nat. Rev. Neurosci. 9, 813-825.

Khachaturian, Z. S. (1989). Calcium, membranes, aging, and Alzheimer's disease. Introduction and overview. Ann. N. Y. Acad. Sci. 568, 1-4.

Khachaturian, Z. S. (1994). Calcium hypothesis of Alzheimer's disease and brain aging. Ann. N. Y. Acad. Sci. 747, 1-11.

Kim, E. Y., Mahmoud, G. S., and Grover, L. M. (2005). REM sleep deprivation inhibits LTP in vivo in area CA1 of rat hippocampus. Neurosci. Lett. 388, 163-167.

Kim, J., Jung, S. C., Clemens, A. M., Petralia, R. S., and Hoffman, D. A. (2007). Regulation of dendritic excitability by activity-dependent trafficking of the A-type $\mathrm{K}+$ channel subunit Kv4.2 in hippocampal neurons. Neuron 54, 933-947.

Kim, J. J., and Diamond, D. M. (2002). The stressed hippocampus, synaptic plasticity and lost memories. Nat. Rev. Neurosci. 3, 453-462.

Kim, J. J., Foy, M. R., and Thompson, R. F. (1996). Behavioral stress modifies hippocampal plasticity through
$\mathrm{N}$-methyl-D-aspartate receptor activation. Proc. Natl. Acad. Sci. U.S.A. 93, 4750-4753.

Kim, J. J., and Haller, J. (2007). Glucocorticoid hyper- and hypofunction: stress effects on cognition and aggression. Ann. N. Y. Acad. Sci. 1113, 291-303.

Kim, J. J., and Yoon, K. S. (1998). Stress: metaplastic effects in the hippocampus. Trends Neurosci. 21, 505-509.

Kirkwood, A., Dudek, S. M., Gold, J. T., Aizenman, C. D., and Bear, M. F. (1993). Common forms of synaptic plasticity in the hippocampus and neocortex in vitro. Science 260, 1518-1521.

Klann, E., Chen, S. J., and Sweatt, J. D. (1993). Mechanism of protein kinase $\mathrm{C}$ activation during the induction and maintenance of long-term potentiation probed using a selective peptide substrate. Proc. Natl. Acad. Sci. U.S.A. 90, 8337-8341.

Klyubin, I., Walsh, D. M., Cullen, W. K., Fadeeva, J. V., Anwyl, R., Selkoe, D. J., and Rowan, M. J. (2004). Soluble Arctic amyloid beta protein inhibits hippocampal long-term potentiation in vivo. Eur. J. Neurosci. 19, 2839-2846.

Knobloch, M., Farinelli, M., Konietzko, U., Nitsch, R. M., and Mansuy, I. M. (2007). Abeta oligomer-mediated long-term potentiation impairment involves protein phosphatase 1-dependent mechanisms. J. Neurosci. 27, 7648-7653.

Kohda, K., Harada, K., Kato, K., Hoshino, A., Motohashi, J., Yamaji, T., Morinobu, S., Matsuoka, N., and Kato, N. (2007). Glucocorticoid receptor activation is involved in producing abnormal phenotypes of single-prolonged stress rats: a putative post-traumatic stress disorder model. Neuroscience 148, 22-33.

Kombian, S. B., and Malenka, R. C. (1994). Simultaneous LTP of nonNMDA- and LTD of NMDA-receptormediated responses in the nucleus accumbens. Nature 368, 242-246.

Konorski, J. (1948). Conditioned Reflexes and Neuron Organization. Cambridge: Cambridge University Press.

Korkotian, E., and Segal, M. (1999). Release of calcium from stores alters the morphology of dendritic spines in cultured hippocampal neurons. Proc. Natl. Acad. Sci. U.S.A. 96, 12068-12072.

Korte, M., Kang, H., Bonhoeffer, T., and Schuman, E. (1998). A role for BDNF in the late-phase of hippocampal long-term potentiation. Neuropharmacology 37, 553-559.

Korwek, K. M., Trotter, J. H., Ladu, M. J., Sullivan, P. M., and Weeber, E. J. (2009). ApoE isoform-dependent changes in hippocampal synaptic function. Mol. Neurodegener. 4, 21.

Kovacs, K. A., Steullet, P., Steinmann, M., Do, K. Q., Magistretti, P. J., Halfon, O., and Cardinaux, J. R. (2007). TORC1 is a calcium- and cAMP-sensitive coincidence detector involved in hippocampal long-term synaptic plasticity. Proc Natl. Acad. Sci. U.S.A. 104, 4700-4705.

Kovalchuk, Y., Hanse, E., Kafitz, K. W. and Konnerth, A. (2002). Postsynaptic induction of BDNF-mediated longterm potentiation. Science 295 , 1729-1734.

Kramar, E. A., Lin, B., Lin, C. Y., Arai, A. C., Gall, C. M., and Lynch, G. (2004). A novel mechanism for the facilitation of theta-induced long-term potentiation by brain-derived neurotrophic factor. J. Neurosci. 24, 5151-5161.

Krugers, H. J., Alfarez, D. N., Karst, H., Parashkouhi, K., van Gemert, N. and Joels, M. (2005). Corticosterone shifts different forms of synaptic potentiation in opposite directions. Hippocampus 15, 697-703.

Krugers, H.J., Mulder, M., Korf, J., Havekes, L., de Kloet, E. R., and Joels, M. (1997). Altered synaptic plasticity in hippocampal CA1 area of apolipoprotein E deficient mice. Neuroreport 8, 2505-2510.

Kuenzi, F., Rosahl, T. W., Morton, R. A., Fitzjohn, S. M., Collingridge, G. L., and Seabrook, G. R. (2003). Hippocampal synaptic plasticity in mice carrying the rd mutation in the gene encoding cGMP phosphodiesterase type 6 (PDE6). Brain Res. 967, 144-151.

Kullmann, D. M., and Nicoll, R. A. (1992), Long-term potentiation is associated with increases in quantal content and quantal amplitude. Nature 357, 240-244.

Kumar, A., Bodhinathan, K., and Foster, T. C. (2009). Susceptibility to calcium dysregulation during brain aging. Front. Aging Neurosci. 1:2. doi: 10.3389/neuro.24.002.2009

Kumar, A., and Foster, T. C. (2002). 17beta-Estradiol benzoate decreases the AHP amplitude in CAl pyramidal neurons. J. Neurophysiol. 88, 621-626.

Kumar, A., and Foster, T. C. (2004) Enhanced long-term potentiation during aging is masked by processes involving intracellular calcium stores. J. Neurophysiol. 91, 2437-2444.

Kumar, A., Thinschmidt, J. S., Foster, T. C., and King, M. A. (2007). Aging effects on the limits and stability of long-term synaptic potentiation and depression in rat hippocampal area CA1. J. Neurophysiol. 98, 594-601.

Landfield, P. W. (1994). Increased hippocampal $\mathrm{Ca} 2+$ channel activity in brain aging and dementia. Hormonal and pharmacologic modulation. Ann. N. Y. Acad. Sci. 747, 351-364.

Landfield, P. W., and Lynch, G. (1977). Impaired monosynaptic potentiation in in vitro hippocampal slices from aged, memory-deficient rats. $J$. Gerontol. 32, 523-533.
Landfield, P. W., McGaugh, J. L., and Lynch, G. (1978). Impaired synaptic potentiation processes in the hippocampus of aged, memory-deficient rats. Brain Res. 150, 85-101.

Landfield, P. W., and Pitler, T. A. (1984). Prolonged Ca2+-dependent after hyperpolarizations in hippocampal neurons of aged rats. Science 226, 1089-1092.

Lante, F., de Jesus Ferreira, M. C., Guiramand, J., Recasens, M., and Vignes, M. (2006). Low-frequency stimulation induces a new form of LTP, metabotropic glutamate (mGlu5) receptor- and PKA-dependent, in the CA1 area of the rat hippocampus. Hippocampus 16, 345-360.

Larson, J., and Lynch, G. (1986). Induction of synaptic potentiation in hippocampus by patterned stimulation involves two events. Science 232, 985-988.

Lauri, S. E., Palmer, M., Segerstrale, M., Vesikansa,A., Taira, T., and Collingridge, G. L. (2007). Presynaptic mechanisms involved in the expression of STP and LTP at CA1 synapses in the hippocampus. Neuropharmacology 52, 1-11.

Lauterborn, J. C., Rex, C. S., Kramar, E., Chen, L. Y., Pandyarajan, V., Lynch, G., and Gall, C. M. (2007). Brain-derived neurotrophic factor rescues synaptic plasticity in a mouse model of fragile $X$ syndrome. J. Neurosci. 27, 10685-10694.

Le Ray, D., Fernandez De Sevilla, D., Belen Porto, A., Fuenzalida, M., and Buno, W. (2004). Heterosynaptic metaplastic regulation of synaptic efficacy in CA1 pyramidal neurons of rat hippocampus. Hippocampus 14, 1011-1025.

Lee, W. L., Anwyl, R., and Rowan, M. (1987). Caffeine inhibits post-tetanic potentiation but does not alter longterm potentiation in the rat hippocampal slice. Brain Res. 426, 250-256.

Leung, L. S., Shen, B., Rajakumar, N., and Ma, J. (2003). Cholinergic activity enhances hippocampal long-term potentiation in CA1 during walking in rats. J. Neurosci. 23, 9297-9304.

Lev-Ram, V., Wong, S. T., Storm, D. R., and Tsien, R. Y. (2002). A new form of cerebellar long-term potentiation is postsynaptic and depends on nitric oxide but not cAMP. Proc. Natl. Acad. Sci. U.S.A. 99, 8389-8393.

Levy, W. B., and Steward, O. (1979). Synapses as associative memory elements in the hippocampal formation. Brain Res. 175, 233-245.

Lewis, P. R., Shute, C. C., and Silver, A. (1967). Confirmation from choline acetylase analyses of a massive cholinergic innervation to the rat hippocampus. J. Physiol. (Lond.) 191, 215-224.

Li, H., Weiss, S. R., Chuang, D. M., Post, R. M., and Rogawski, M. A. (1998). Bidirectional synaptic plasticity in the rat basolateral 
amygdala: characterization of an activity-dependent switch sensitive to the presynaptic metabotropic glutamate receptor antagonist $2 \mathrm{~S}$-alphaethylglutamic acid. J. Neurosci. 18, 1662-1670.

Li, H. B., Jackson, M. F., Yang, K., Trepanier, C., Salter, M. W., Orser, B. A., and Macdonald, J. F. (2010a). Plasticity of synaptic GluN receptors is required for the Src-dependent induction of long-term potentiation at CA3-CA1 synapses. Hippocampus. doi: 10.1002/ hipo.20818. [Epub ahead of print].

Li, Q., Zhao, H., Zhao, M., Zhang, Z., and Li, Y. (2010b). Chronic green tea catechins administration prevents oxidative stress-related brain aging in C57BL/6J mice. Brain Res. 1353, 28-35.

Li, S., Cullen, W. K., Anwyl, R., and Rowan, M. J. (2003). Dopamine-dependent facilitation of LTP induction in hippocampal CA1 by exposure to spatial novelty. Nat. Neurosci. 6, 526-531.

Li, Z., Zhou, Q., Li, L., Mao, R., Wang, M., Peng, W., Dong, Z., Xu, L., and Cao, J. (2005). Effects of unconditioned and conditioned aversive stimuli in an intense fear conditioning paradigm on synaptic plasticity in the hippocampal CA1 area in vivo. Hippocampus $15,815-824$

Liao, D., Hessler, N. A., and Malinow, R. (1995). Activation of postsynaptically silent synapses during pairing-induced LTP in CA1 region of hippocampal slice. Nature 375, 400-404.

Lieberman, D. N., and Mody, I. (1994). Regulation of NMDA channel function by endogenous $\mathrm{Ca}(2+)$ dependent phosphatase. Nature 369, 235-239.

Lilliehook, C., Bozdagi, O., Yao, J., Gomez-Ramirez, M., Zaidi, N. F., Wasco, W., Gandy, S., Santucci, A. C., Haroutunian, V., Huntley, G. W., and Buxbaum, J. D. (2003). Altered Abeta formation and long-term potentiation in a calsenilin knock-out. J. Neurosci. 23, 9097-9106.

Lin, C. H., Yeh, S. H., Leu, T. H., Chang, W. C., Wang, S. T., and Gean, P. W. (2003). Identification of calcineurin as a key signal in the extinction of fear memory. J. Neurosci. 23, 1574-1579.

Lipton, S. A., Choi, Y. B., Takahashi, H., Zhang, D., Li, W., Godzik, A., and Bankston, L. A. (2002). Cysteine regulation of protein function - as exemplified by NMDA-receptor modulation. Trends Neurosci. 25, 474-480.

Lisman, J. (1994). The CaM kinase II hypothesis for the storage of synaptic memory. Trends Neurosci. 17, 406-412.

Lister, J. P., and Barnes, C. A. (2009). Neurobiological changes in the hippocampus during normative aging. Arch. Neurol. 66, 829-833.
Loane, D. J., Deighan, B. F., Clarke, R. M., Griffin, R. J., Lynch, A. M., and Lynch, M. A. (2009). Interleukin-4 mediates the neuroprotective effects of rosiglitazone in the aged brain. Neurobiol. Aging 30, 920-931.

Lovinger, D. M. (2010). Neurotransmitter roles in synaptic modulation, plasticity and learning in the dorsal striatum. Neuropharmacology 58, 951-961.

Lu, C., Chan, S. L., Fu, W., and Mattson, M. P. (2002). The lipid peroxidation product 4-hydroxynonenal facilitates opening of voltage-dependent $\mathrm{Ca} 2+$ channels in neurons by increasing protein tyrosine phosphorylation. J. Biol. Chem. 277, 24368-24375.

Lu, C., Chan, S. L., Haughey, N., Lee, W. T., and Mattson, M.P. (2001). Selective and biphasic effect of the membrane lipid peroxidation product 4-hydroxy2,3-nonenal on N-methyl-D-aspartate channels. J. Neurochem. 78, 577-589.

Lu, K. T., Wu, S. P., and Gean, P. W. (1999a). Promotion of forskolininduced long-term potentiation of synaptic transmission by caffeine in area $\mathrm{CA} 1$ of the rat hippocampus. Chin. J. Physiol. 42, 249-253.

Lu, Y. F., Kandel, E. R., and Hawkins, R. D. (1999b). Nitric oxide signaling contributes to late-phase LTP and CREB phosphorylation in the hippocampus. J. Neurosci. 19, 10250-10261.

Luo, T., and Leung, L. S. (2010). Endogenous histamine facilitates long-term potentiation in the hippocampus during walking. J. Neurosci. 30, 7845-7852.

Lynch, A. M., Loane, D. J., Minogue, A. M., Clarke, R. M., Kilroy, D., Nally, R. E., Roche, O. J., O'Connell, F., and Lynch, M. A. (2007a). Eicosapentaenoic acid confers neuroprotection in the amyloid-beta challenged aged hippocampus. Neurobiol. Aging 28, 845-855.

Lynch, G., Kramar, E. A., Rex, C. S., Jia, Y., Chappas, D., Gall, C. M., and Simmons, D. A. (2007b). Brainderived neurotrophic factor restores synaptic plasticity in a knock-in mouse model of Huntington's disease. J. Neurosci. 27, 4424-4434.

Lynch, G. S., Dunwiddie, T., and Gribkoff, V. (1977). Heterosynaptic depression: a postsynaptic correlate of long-term potentiation. Nature 266, 737-739.

Lynch, M. A. (1997). Age-related changes in synaptic plasticity in rat hippocampus. J. Neurophysiol. 501, 5S-6S.

Lynch, M.A. (1998a). Age-related impairment in long-term potentiation in hippocampus: a role for the cytokine, interleukin-1 beta? Prog. Neurobiol. $56,571-589$.

Lynch, M. A. (1998b). Analysis of the mechanisms underlying the age-related impairment in long-term potentiation in the rat. Rev. Neurosci. 9, 169-201.
Lynch, M. A. (2004). Long-term potentiation and memory. Physiol. Rev. 84, 87-136.

Lynch, M. A. (2010). Age-related neuroinflammatory changes negatively impact on neuronal function. Front. Aging Neurosci. 1:6. doi: 10.3389/ neuro.24.006.2009

Lynch, M. A., and Voss, K. L. (1994) Membrane arachidonic acid concentration correlates with age and induction of long-term potentiation in the dentate gyrus in the rat. Eur. J. Neurosci. 6, 1008-1014.

Lyons, A., Downer, E. J., Crotty, S., Nolan, Y. M., Mills, K. H., and Lynch, M. A (2007). CD200 ligand receptor interaction modulates microglial activation in vivo and in vitro: a role for IL-4. J. Neurosci. 27, 8309-8313.

MacDonald, J. F., Jackson, M. F., and Beazely, M. A. (2006). Hippocampal long-term synaptic plasticity and signal amplification of NMDA receptors. Crit. Rev. Neurobiol. 18, 71-84.

Madison, D. V., and Schuman, E. M. (1991). LTP, post or pre? A look at the evidence for the locus of long-term potentiation. New Biol. 3, 549-557.

Magee, J.C. (2000). Dendritic integration of excitatory synaptic input. Nat. Rev. Neurosci. 1, 181-190.

Magee, J. C., and Johnston, D. (1997). A synaptically controlled, associative signal for Hebbian plasticity in hippocampal neurons. Science 275, 209-213.

Maggi, L., Trettel, F., Scianni, M., Bertollini, C., Eusebi, F., Fredholm, B. B., and Limatola, C. (2009). LTP impairment by fractalkine/CX3CL1 in mouse hippocampus is mediated through the activity of adenosine receptor type 3 (A3R). J. Neuroimmunol. 215, 36-42.

Maggio, N., and Segal, M. (2007). Striking variations in corticosteroid modulation of long-term potentiation along the septotemporal axis of the hippocampus. J. Neurosci. 27, 5757-5765

Maggio, N., and Segal, M. (2010) Corticosteroid regulation of synaptic plasticity in the hippocampus. ScientificWorldJournal 10, 462-469.

Maggio, N., and Segal, M. (2011). Persistent changes in ability to express long-term potentiation/depression in the rat hippocampus after juvenile/adult stress. Biol. Psychiatry 69, 748-753.

Magnusson, K. R., Bai, L., and Zhao, X. (2005). The effects of aging on different C-terminal splice forms of the zetal(NR1) subunit of the N-methyl$\mathrm{d}$-aspartate receptor in mice. Brain Res. Mol. Brain Res. 135, 141-149.

Magnusson, K. R., Brim, B. L., and Das, S. R. (2010). Selective vulnerabilities of N-methyl-D-aspartate (NMDA) receptors during brain aging. Front Aging Neurosci. 2:11. doi: 10.3389/ fnagi.2010.00011
Magnusson, K. R., Kresge, D., and Supon, J. (2006). Differential effects of aging on NMDA receptors in the intermediate versus the dorsal hippocampus. Neurobiol. Aging 27, 324-333.

Magnusson, K. R., Nelson, S. E., and Young, A. B. (2002). Age-related changes in the protein expression of subunits of the NMDA receptor. Brain Res. Mol. Brain Res. 99, 40-45.

Mahley, R. W. (1988). Apolipoprotein E: cholesterol transport protein with expanding role in cell biology. Science 240, 622-630

Mahley, R. W., Innerarity, T. L., Rall, S. C. Jr., and Weisgraber, K. H. (1984). Plasma lipoproteins: apolipoprotein structure and function. J. Lipid Res. 25, 1277-1294.

Malenka, R. C. (1994). Synaptic plasticity in the hippocampus: LTP and LTD. Cell 78, 535-538.

Malenka, R. C. (2003). The long-term potential of LTP. Nat. Rev. Neurosci. 4, 923-926.

Malenka, R. C., and Bear, M. F. (2004). LTP and LTD: an embarrassment of riches. Neuron 44, 5-21.

Malenka, R. C., and Nicoll, R. A. (1999). Long-term potentiation--a decade of progress? Science 285, 1870-1874.

Martin, E. D., and Buno, W. (2003). Caffeine-mediated presynaptic long-term potentiation in hippocampal CAl pyramidal neurons. $J$. Neurophysiol. 89, 3029-3038.

Martin, S. J., Grimwood, P.D., and Morris, R. G. (2000). Synaptic plasticity and memory: an evaluation of the hypothesis. Annu. Rev. Neurosci. 23, 649-711.

Masliah, E., Mallory, M., Veinbergs, I., Miller, A., and Samuel, W. (1996). Alterations in apolipoprotein E expression during aging and neurodegeneration. Prog. Neurobiol. 50, 493-503.

Masliah, E., Samuel, W., Veinbergs, I., Mallory, M., Mante, M., and Saitoh, T. (1997). Neurodegeneration and cognitive impairment in apoE-deficient mice is ameliorated by infusion of recombinant apoE. Brain Res. 751, 307-314.

Massicotte, G., Oliver, M. W., Lynch, G., and Baudry, M. (1990). Effect of bromophenacyl bromide, a phospholipase A2 inhibitor, on the induction and maintenance of LTP in hippocampal slices. Brain Res. 537, 49-53.

Massicotte, G., Vanderklish, P., Lynch, G., and Baudry, M. (1991). Modulation of DL-alpha-amino-3-hydroxy5-methyl-4-isoxazolepropionic acid/quisqualate receptors by phospholipase A2: a necessary step in long-term potentiation? Proc. Natl. Acad. Sci. U.S.A. 88, 1893-1897.

Mattson, M. P. (2007). Calcium and neurodegeneration. Aging Cell 6, 337-350. Mattson, M. P., LaFerla, F. M., Chan, S. L., Leissring, M. A., Shepel, P. N., and 
Geiger,J.D. (2000). Calcium signaling in the ER: its role in neuronal plasticity and neurodegenerative disorders. Trends Neurosci. 23, 222-229.

Mayford, M., Wang, J., Kandel, E. R., and O'Dell, T. J. (1995). CaMKII regulates the frequency-response function of hippocampal synapses for the production of both LTD and LTP. Cell 81, 891-904

McDermott, C. M., LaHoste, G. J., Chen, C., Musto, A., Bazan, N. G., and Magee, J. C. (2003). Sleep deprivation causes behavioral, synaptic, and membrane excitability alterations in hippocampal neurons. J. Neurosci. 23, 9687-9695.

McEwen, B. S. (1994). Corticosteroids and hippocampal plasticity. Ann. N. Y. Acad. Sci. 746, 134-142; discussion 142-134, 178-139.

McEwen, B. S. (1999). Stress and the aging hippocampus. Front. Neuroendocrinol. 20, 49-70.

McEwen, B. S. (2008). Central effects of stress hormones in health and disease: understanding the protective and damaging effects of stress and stress mediators. Eur. J. Pharmacol. 583, 174-185.

McEwen, B. S., and Sapolsky, R.M. (1995). Stress and cognitive function. Curr. Opin. Neurobiol. 5, 205-216.

McGahon, B., Clements, M.P., and Lynch, M. A. (1997). The ability of aged rats to sustain long-term potentiation is restored when the age-related decrease in membrane arachidonic acid concentration is reversed. Neuroscience 81, 9-16.

Mesulam, M. (2004). The cholinergic lesion of Alzheimer's disease: pivotal factor or side show? Learn. Mem. 11, 43-49.

Middei, S., Roberto, A., Berretta, N., Panico, M. B., Lista, S., Bernardi, G., Mercuri, N. B., Ammassari-Teule, M., and Nistico, R. (2010). Learning discloses abnormal structural and functional plasticity at hippocampal synapses in the APP23 mouse model of Alzheimer's disease. Learn. Mem. 17, 236-240.

Min, S. S., Quan, H. Y., Ma, J., Han, J. S., Jeon, B. H., and Seol, G. H. (2009). Chronic brain inflammation impairs two forms of long-term potentiation in the rat hippocampal CA1 area. Neurosci. Lett. 456, 20-24.

Minichiello, L. (2009). TrkB signalling pathways in LTP and learning. Nat. Rev. Neurosci. 10, 850-860.

Misner, D. L., and Sullivan, J. M. (1999). Mechanism of cannabinoid effects on long-term potentiation and depression in hippocampal CA1 neurons. $J$. Neurosci. 19, 6795-6805.

Miyamoto, E. (2006). Molecular mechanism of neuronal plasticity: induction and maintenance of long-term potentiation in the hippocampus. J. Pharmacol. Sci. 100, 433-442.

Monfort, P., Erceg, S., Piedrafita, B., Llansola, M., and Felipo, V. (2007). Chronic liver failure in rats impairs glutamatergic synaptic transmission and long-term potentiation in hippocampus and learning ability. Eur. J. Neurosci. 25, 2103-2111.

Moore, C. I., Browning, M. D., and Rose, G. M. (1993). Hippocampal plasticity induced by primed burst, but not long-term potentiation, stimulation is impaired in area CA1 of aged Fischer 344 rats. Hippocampus 3, 57-66.

Moretti, P., Levenson, J. M., Battaglia, F., Atkinson, R., Teague, R., Antalffy, B., Armstrong, D., Arancio, O., Sweatt, J. D., and Zoghbi, H.Y. (2006). Learning and memory and synaptic plasticity are impaired in a mouse model of Rett syndrome. J. Neurosci. 26, 319-327.

Morris, R. G., Anderson, E., Lynch, G. S., and Baudry, M. (1986). Selective impairment of learning and blockade of long-term potentiation by an N-methyl-D-aspartate receptor antagonist, AP5. Nature 319, 774-776.

Motanis, H., and Maroun, M. (2010). Exposure to a novel context following contextual fear conditioning enhances the induction of hippocampal longterm potentiation. Eur. J. Neurosci. $32,840-846$.

Moyer, J. R. Jr., Thompson, L. T., Black, J.P., and Disterhoft,J.F.(1992). Nimodipine increases excitability of rabbit CAl pyramidal neurons in an age- and concentration-dependent manner. $J$. Neurophysiol. 68, 2100-2109.

Muller, W. E., Hartmann, H., Eckert, A., Velbinger, K., and Forstl, H. (1996). Free intracellular calcium in aging and Alzheimer's disease. Ann. N. Y. Acad. Sci. 786, 305-320.

Munoz, P., Humeres, A., Elgueta, C., Kirkwood, A., Hidalgo, C., and Nunez, M. T. (2011). Iron mediates N-methylD-aspartate receptor-dependent stimulation of calcium-induced pathways and hippocampal synaptic plasticity. $J$. Biol. Chem. 286, 13382-13392.

Murphy, G. G., Fedorov, N. B., Giese, K. P., Ohno, M., Friedman, E., Chen, R., and Silva, A. J. (2004). Increased neuronal excitability, synaptic plasticity, and learning in aged Kvbetal.1 knockout mice. Curr. Biol. 14, 1907-1915.

Murphy, K. P., Carter, R. J., Lione, L. A., Mangiarini, L., Mahal, A., Bates, G. P., Dunnett, S. B., and Morton, A. J. (2000). Abnormal synaptic plasticity and impaired spatial cognition in mice transgenic for exon 1 of the human Huntington's disease mutation. $J$. Neurosci. 20, 5115-5123.

Murphy, K. P., Reid, G. P., Trentham, D. R., and Bliss, T. V. (1997). Activation of NMDA receptors is necessary for the induction of associative long-term potentiation in area CA1 of the rat hippocampal slice. J. Physiol. (Lond.) 504 (Pt 2), 379-385.

Murray, C. A., and Lynch, M. A. (1998a). Dietary supplementation with vita$\min \mathrm{E}$ reverses the age-related deficit in long term potentiation in dentate gyrus. J. Biol. Chem. 273, 12161-12168.

Murray, C. A., and Lynch, M. A. (1998b). Evidence that increased hippocampal expression of the cytokine interleukin-1 beta is a common trigger for age- and stress-induced impairments in long-term potentiation. $J$. Neurosci. 18, 2974-2981.

Narayanan, R., and Johnston, D. (2010). The $h$ current is a candidate mechanism for regulating the sliding modification threshold in a BCM-like synaptic learning rule. J. Neurophysiol. 104, 1020-1033.

Navakkode, S., Sajikumar, S., and Frey, J. U. (2004). The type IV-specific phosphodiesterase inhibitor rolipram and its effect on hippocampal long-term potentiation and synaptic tagging. $J$. Neurosci. 24, 7740-7744.

Nicoll, R. A. (2003). Expression mechanisms underlying long-term potentiation: a postsynaptic view. Philos. Trans R. Soc. Lond. B Biol. Sci. 358, 721-726.

Nicoll, R. A., and Malenka, R. C. (1999). Expression mechanisms underlying NMDA receptor-dependent longterm potentiation. Ann. N. Y. Acad. Sci. 868, 515-525.

Niewiadomska, G., BaksalerskaPazera, M., and Riedel, G. (2009). The septo-hippocampal system, learning and recovery of function. Prog. Neuropsychopharmacol. Biol. Psychiatry 33, 791-805.

Nishizuka, Y. (1992). Intracellular signaling by hydrolysis of phospholipids and activation of protein kinase C. Science 258, 607-614.

Nolan, Y., Maher, F. O., Martin, D. S., Clarke, R. M., Brady, M. T., Bolton, A. E., Mills, K. H., and Lynch, M. A (2005). Role of interleukin-4 in regulation of age-related inflammatory changes in the hippocampus. J. Biol. Chem. 280, 9354-9362.

Norris, C. M., Halpain, S., and Foster, T.C. (1998). Reversal of age-related alterations in synaptic plasticity by blockade of L-type Ca2+ channels. J. Neurosci. 18, 3171-3179.

Norris, C. M., Korol, D. L., and Foster T. C. (1996). Increased susceptibility to induction of long-term depression and long- term potentiation reversal during aging. J. Neurosci. 16, 5382-5392.

Nosten-Bertrand, M., Errington, M. L., Murphy, K. P., Tokugawa, Y., Barboni, E., Kozlova, E., Michalovich, D. Morris, R. G., Silver, J., Stewart, C. L.,
Bliss, T. V., and Morris, R. J. (1996). Normal spatial learning despite regional inhibition of LTP in mice lacking Thy-1. Nature 379, 826-829.

Nugent, F. S., Hwong, A. R., Udaka, Y., and Kauer, J. A. (2008). Highfrequency afferent stimulation induces long-term potentiation of field potentials in the ventral tegmental area. Neuropsychopharmacology 33, 1704-1712.

Nugent, F. S., Penick, E. C., and Kauer, J. A. (2007). Opioids block long-term potentiation of inhibitory synapses. Nature 446, 1086-1090.

O’Dell, T. J., Connor, S. A., Gelinas, J. N., and Nguyen, P. V. (2010). Viagra for your synapses: enhancement of hippocampal long-term potentiation by activation of beta-adrenergic receptors. Cell. Signal. 22, 728-736.

O’Dell, T. J., Huang, P. L., Dawson, T. M., Dinerman, J. L., Snyder, S. H., Kandel, E. R., and Fishman, M. C. (1994). Endothelial NOS and the blockade of LTP by NOS inhibitors in mice lacking neuronal NOS. Science 265, 542-546.

O'Donnell, E., Vereker, E., and Lynch, M. A. (2000). Age-related impairment in LTP is accompanied by enhanced activity of stress-activated protein kinases: analysis of underlying mechanisms. Eur. J. Neurosci. 12, 345-352.

Okada, D., Yamagishi, S., and Sugiyama, H. (1989). Differential effects of phospholipase inhibitors in long-term potentiation in the rat hippocampal mossy fiber synapses and Schaffer/ commissural synapses. Neurosci. Lett. $100,141-146$

Ondrejcak, T., Klyubin, I., Hu, N. W., Barry, A.E., Cullen, W. K., and Rowan, M. J. (2010). Alzheimer's disease amyloid beta-protein and synaptic function. Neuromolecular Med. 12, 13-26.

Otmakhova, N. A., and Lisman, J. E. (1996). D1/D5 dopamine receptor activation increases the magnitude of early long-term potentiation at CA1 hippocampal synapses. J. Neurosci. 16, 7478-7486.

Panula, P., Pirvola, U., Auvinen, S., and Airaksinen, M. S. (1989). Histamineimmunoreactive nerve fibers in the rat brain. Neuroscience 28, 585-610.

Parameshwaran, K., Sims, C., Kanju, P., Vaithianathan, T., Shonesy, B. C. Dhanasekaran, M., Bahr, B. A., and Suppiramaniam, V. (2007). Amyloid beta-peptide Abeta(1-42) but not Abeta(1-40) attenuates synaptic AMPA receptor function. Synapse 61, 367-374.

Parihar, M. S., Kunz, E. A., and Brewer, G. J. (2008). Age-related decreases in $\mathrm{NAD}(\mathrm{P}) \mathrm{H}$ and glutathione cause redox declines before ATP loss during glutamate treatment of hippocampal 
neurons. J. Neurosci. Res. 86, 2339-2352.

Patel, P.D., Lopez, J. F., Lyons, D. M., Burke, S., Wallace, M., and Schatzberg, A. F. (2000). Glucocorticoid and mineralocorticoid receptor mRNA expression in squirrel monkey brain. J. Psychiatr. Res. 34, 383-392.

Pavlides, C., Nivon, L. G., and McEwen, B. S. (2002). Effects of chronic stress on hippocampal long-term potentiation. Hippocampus 12, 245-257.

Pavlides, C., Watanabe, Y., and McEwen, B. S. (1993). Effects of glucocorticoids on hippocampal long-term potentiation. Hippocampus 3, 183-192.

Pennartz, C. M., Ameerun, R. F. Groenewegen, H. J., and Lopes da Silva, F. H. (1993). Synaptic plasticity in an in vitro slice preparation of the rat nucleus accumbens. Eur. J. Neurosci. 5, 107-117.

Phillips, R. G., Meier, T. J., Giuli, L. C., McLaughlin, J. R., Ho, D. Y., and Sapolsky, R. M. (1999). Calbindin D28K gene transfer via herpes simplex virus amplicon vector decreases hippocampal damage in vivo following neurotoxic insults. J. Neurochem. 73, 1200-1205.

Pieta Dias, C., Martins de Lima, M. N., Presti-Torres, J., Dornelles, A., Garcia, V. A., Siciliani Scalco, F., Rewsaat Guimaraes, M., Constantino, L., Budni, P., Dal-Pizzol, F., and Schroder, N. (2007). Memantine reduces oxidative damage and enhances long-term recognition memory in aged rats. Neuroscience 146, 1719-1725.

Pitler, T. A., and Landfield, P. W. (1990). Aging-related prolongation of calcium spike duration in rat hippocampal slice neurons. Brain Res. 508, 1-6.

Poe, G. R., Walsh, C. M., and Bjorness, T. E. (2010). Cognitive neuroscience of sleep. Prog. Brain Res. 185, 1-19.

Poon, H. F., Calabrese, V., Calvani, M., and Butterfield, D. A. (2006). Proteomics analyses of specific protein oxidation and protein expression in aged rat brain and its modulation by L-acetylcarnitine: insights into the mechanisms of action of this proposed therapeutic agent for CNS disorders associated with oxidative stress. Antioxid. Redox Signal. 8, 381-394.

Potier, B., Lamour, Y., and Dutar, P. (1993). Cholinergic and non-cholinergic synaptic mechanisms in the aged rat hippocampus. Ann. N. Y. Acad. Sci. 695, 236-240.

Powell, C. M., Johnston, D., and Sweatt, J. D. (1994). Autonomously active protein kinase $\mathrm{C}$ in the maintenance phase of N-methyl-D-aspartate receptorindependent long term potentiation. J. Biol. Chem. 269, 27958-27963.
Randall, R. D., Lee, S. Y., Meyer, J. H., Wittenberg, G. F., and Gruol, D. L. (1995). Acute alcohol blocks neurosteroid modulation of synaptic transmission and long-term potentiation in the rat hippocampal slice. Brain Res. 701, 238-248.

Ravassard, P., Pachoud, B., Comte, J. C., Mejia-Perez, C., Scote-Blachon, C., Gay, N., Claustrat, B., Touret, M., Luppi, P. H., and Salin, P. A. (2009). Paradoxical (REM) sleep deprivation causes a large and rapidly reversible decrease in long-term potentiation, synaptic transmission, glutamate receptor protein levels, and ERK/ MAPK activation in the dorsal hippocampus. Sleep 32, 227-240.

Raymond, C. R., and Redman, S. J. (2002). Different calcium sources are narrowly tuned to the induction of different forms of LTP. J. Neurophysiol. 88, 249-255.

Rebola, N., Lujan, R., Cunha, R. A., and Mulle, C. (2008). Adenosine A2A receptors are essential for long-term potentiation of NMDA-EPSCs at hippocampal mossy fiber synapses. Neuron 57, 121-134.

Reul, J. M., and de Kloet, E. R. (1985). Two receptor systems for corticosterone in rat brain: microdistribution and differential occupation. Endocrinology 117, 2505-2511.

Rex, C. S., Kramar, E. A., Colgin, L. L., Lin, B., Gall, C. M., and Lynch, G. (2005). Long-term potentiation is impaired in middle-aged rats: regional specificity and reversal by adenosine receptor antagonists. J. Neurosci. 25, 5956-5966.

Roberson, E. D., English, J.D., and Sweatt, J. D. (1996). A biochemist's view of longterm potentiation. Learn. Mem.3, 1-24.

Rocher, C., Spedding, M., Munoz, C., and Jay, T.M. (2004).Acute stress-induced changes in hippocampal/prefrontal circuits in rats: effects of antidepressants. Cereb. Cortex 14, 224-229.

Rogan, M. T., Staubli, U.V., and LeDoux, J. E. (1997). Fear conditioning induces associative long-term potentiation in the amygdala. Nature 390, 604-607.

Rose, C. R., and Konnerth, A. (2001). Stores not just for storage. Intracellular calcium release and synaptic plasticity. Neuron 31, 519-522.

Rose, G. M., and Dunwiddie, T. V. (1986). Induction of hippocampal long-term potentiation using physiologically patterned stimulation. Neurosci. Lett. 69, 244-248.

Rosenzweig, E. S., and Barnes, C. A. (2003). Impact of aging on hippocampal function: plasticity, network dynamics, and cognition. Prog. Neurobiol. 69, 143-179.
Rothman, S. M., and Mattson, M. P. (2010). Adverse stress, hippocampal networks, and Alzheimer's disease. Neuromolecular Med. 12, 56-70.

Routtenberg, A. (1999). Tagging the Hebb synapse. Trends Neurosci. 22, 255-256.

Ryan, B. K., Anwyl, R., and Rowan, M. J. (2008). 5-HT2 receptor-mediated reversal of the inhibition of hippocampal long-term potentiation by acute inescapable stress. Neuropharmacology $55,175-182$.

Sabeti, J., Nelson, T. E., Purdy, R. H., and Gruol, D. L. (2007). Steroid pregnenolone sulfate enhances NMDAreceptor-independent long-term potentiation at hippocampal CA1 synapses: role for L-type calcium channels and sigma-receptors. Hippocampus 17, 349-369.

Sacktor, T. C. (2008). PKMzeta, LTP maintenance, and the dynamic molecular biology of memory storage. Prog. Brain Res. 169, 27-40.

Sacktor, T. C., Osten, P., Valsamis, H. Jiang, X., Naik, M. U., and Sublette, E. (1993). Persistent activation of the zeta isoform of protein kinase $\mathrm{C}$ in the maintenance of long-term potentiation. Proc. Natl. Acad. Sci. U.S.A. 90 8342-8346.

Sah, P., and Bekkers, J. M. (1996). Apical dendritic location of slow afterhyperpolarization current in hippocampal pyramidal neurons: implications for the integration of long-term potentiation. J. Neurosci. 16, 4537-4542.

Sajikumar, S., Li, Q., Abraham, W. C., and Xiao, Z. C. (2009). Priming of shortterm potentiation and synaptic tagging/capture mechanisms by ryanodine receptor activation in rat hippocampal CA1. Learn. Mem. 16, 178-186.

Salin, P. A., Malenka, R. C., and Nicoll, R. A. (1996). Cyclic AMP mediates a presynaptic form of LTP at cerebellar parallel fiber synapses. Neuron 16 797-803.

Sallert, M., Rantamaki, T., Vesikansa, A., Anthoni, H., Harju, K., YliKauhaluoma, J., Taira, T., Castren, E., and Lauri, S. E. (2009). Brainderived neurotrophic factor controls activity-dependent maturation of CAl synapses by downregulating tonic activation of presynaptic kainate receptors. J. Neurosci. 29, 11294-11303.

Sanes, J. R., and Lichtman, J. W. (1999). Can molecules explain long-term potentiation? Nat. Neurosci. 2, 597-604.

Schmechel, D. E., Saunders, A. M. Strittmatter, W. J., Crain, B. J., Hulette, C. M., Joo, S. H., Pericak-Vance, M. A., Goldgaber,D., and Roses, A.D. (1993). Increased amyloid beta-peptide deposition in cerebral cortex as a consequence of apolipoprotein E genotype in late-onset Alzheimer disease. Proc. Natl. Acad. Sci. U.S.A. 90, 9649-9653. Schmid, A. W., Freir, D. B., and Herron, C. E. (2008). Inhibition of LTP in vivo by beta-amyloid peptide in different conformational states. Brain Res. 1197, 135-142.

Schmid, A. W., Lynch, M. A., and Herron, C.E. (2009). The effects of IL-1 receptor antagonist on beta amyloid mediated depression of LTP in the rat CA1 in vivo. Hippocampus 19, 670-676.

Schotanus, S. M., and Chergui, K. (2008). Long-term potentiation in the nucleus accumbens requires both NR2A- and NR2B-containing N-methyl-Daspartate receptors. Eur. J. Neurosci. 27, 1957-1964.

Schummers, J., Bentz, S., and Browning, M. D. (1997). Ethanol's inhibition of LTP may not be mediated solely via direct effects on the NMDA receptor. Alcohol. Clin. Exp. Res. 21, 404-408.

Schwarzbach, E., Bonislawski, D. P. Xiong, G., and Cohen, A. S. (2006). Mechanisms underlying the inability to induce area CA1 LTP in the mouse after traumatic brain injury. Hippocampus 16, 541-550.

Segev, I., and London, M. (2000). Untangling dendrites with quantitative models. Science 290, 744-750.

Serrano, F., and Klann, E. (2004). Reactive oxygen species and synaptic plasticity in the aging hippocampus. Ageing Res. Rev. 3, 431-443.

Shankar, G. M., Li, S., Mehta, T.H., GarciaMunoz,A., Shepardson, N.E., Smith, I., Brett, F. M., Farrell, M. A., Rowan, M. J., Lemere, C. A., Regan, C. M., Walsh, D. M., Sabatini, B. L., and Selkoe, D. J. (2008). Amyloid-beta protein dimers isolated directly from Alzheimer's brains impair synaptic plasticity and memory. Nat. Med. 14, 837-842.

Shankar, S., Teyler, T. J., and Robbins, N. (1998). Aging differentially alters forms of long-term potentiation in rat hippocampal area CA1. J. Neurophysiol. 79, 334-341.

Shi, L., Linville, M. C., Tucker, E. W., Sonntag, W.E., and Brunso-Bechtold, J. K. (2005). Differential effects of aging and insulin-like growth factor-1 on synapses in CA1 of rat hippocampus. Cereb. Cortex 15, 571-577.

Shipton, O. A., Leitz, J. R., Dworzak, J., Acton, C. E., Tunbridge, E. M., Denk, F., Dawson, H. N., Vitek, M. P., WadeMartins, R., Paulsen, O., and VargasCaballero, M. (2011). Tau protein is required for amyloid \{beta\}-induced impairment of hippocampal longterm potentiation. J. Neurosci. 31, 1688-1692.

Shors, T. J., Gallegos, R. A., and Breindl, A. (1997). Transient and persistent consequences of acute stress on long-term 
potentiation (LTP), synaptic efficacy, theta rhythms and bursts in area CAl of the hippocampus. Synapse 26, 209-217.

Shors, T. J., Seib, T. B., Levine, S., and Thompson, R. F. (1989). Inescapable versus escapable shock modulates long-term potentiation in the rat hippocampus. Science 244, 224-226.

Siarey, R. J., Villar, A. J., Epstein, C. J., and Galdzicki,Z. (2005). Abnormal synaptic plasticity in the Ts1Cje segmental trisomy 16 mouse model of Down syndrome. Neuropharmacology 49, 122-128.

Sigurdsson, T., Doyere, V., Cain, C. K., and LeDoux, J. E. (2007). Long-term potentiation in the amygdala: a cellular mechanism of fear learning and memory. Neuropharmacology 52, 215-227.

Simons, S. B., Escobedo, Y., Yasuda, R., and Dudek, S. M. (2009). Regional differences in hippocampal calcium handling provide a cellular mechanism for limiting plasticity. Proc. Natl. Acad. Sci. U.S.A. 106, 14080-14084.

Slanina, K.A., Roberto, M., and Schweitzer, P. (2005). Endocannabinoids restrict hippocampal long-term potentiation via CB1. Neuropharmacology 49, 660-668.

Sourdet, V., Russier, M., Daoudal, G., Ankri, N., and Debanne, D. (2003). Long-term enhancement of neuronal excitability and temporal fidelity mediated by metabotropic glutamate receptor subtype 5. J. Neurosci. 23, 10238-10248.

Squier, T. C. (2001). Oxidative stress and protein aggregation during biological aging. Exp. Gerontol. 36, 1539-1550.

Staubli, U., and Otaky, N. (1994). Serotonin controls the magnitude of LTP induced by theta bursts via an action on NMDA-receptor-mediated responses. Brain Res. 643, 10-16.

Stephens, D.N., Ripley, T. L., Borlikova, G., Schubert, M., Albrecht, D., Hogarth, L., and Duka, T. (2005). Repeated ethanol exposure and withdrawal impairs human fear conditioning and depresses long-term potentiation in rat amygdala and hippocampus. Biol. Psychiatry 58, 392-400.

Sterlemann, V., Rammes, G., Wolf, M., Liebl, C., Ganea, K., Muller, M. B., and Schmidt, M.V. (2010). Chronic social stress during adolescence induces cognitive impairment in aged mice. Hippocampus 20, 540-549.

Storm-Mathisen, J., and Guldberg, H. C. (1974). 5-Hydroxytryptamine and noradrenaline in the hippocampal region: effect of transection of afferent pathways on endogenous levels, high affinity uptake and some transmitterrelated enzymes. J. Neurochem. 22, 793-803.
Sui, L., Anderson, W. L., and Gilbert, M. E. (2005). Impairment in short-term but enhanced long-term synaptic potentiation and ERK activation in adult hippocampal area CA1 following developmental thyroid hormone insufficiency. Toxicol. Sci. 85, 647-656.

Suzuki, K., Nakamura, M., Hatanaka, Y., Kayanoki, Y., Tatsumi, H., and Taniguchi, N. (1997). Induction of apoptotic cell death in human endothelial cells treated with snake venom: implication of intracellular reactive oxygen species and protective effects of glutathione and superoxide dismutases. J. Biochem. 122, 1260-1264.

Swant, J., Chirwa, S., Stanwood, G., and Khoshbouei, H. (2010). Methamphetamine reduces LTP and increases baseline synaptic transmission in the CA1 region of mouse hippocampus. PLoS ONE 5, e11382. doi: 10.1371/journal.pone.0011382

Sweatt, J. D. (1999). Toward a molecular explanation for long-term potentiation. Learn. Mem. 6, 399-416.

Sweatt, J. D. (2003). Mechanisms of Memory. Houston, TX: Elsevier Academic Press.

Tachibana, K., Matsumoto, M., Togashi, H., Kojima, T., Morimoto, Y., Kemmotsu, O., and Yoshioka, M. (2004). Milnacipran, a serotonin and noradrenaline reuptake inhibitor, suppresses long-term potentiation in the rat hippocampal CAl field via 5 -HT1A receptors and alpha 1-adrenoceptors. Neurosci. Lett. 357, 91-94.

Taqatqeh, F., Mergia, E., Neitz, A., Eysel, U. T., Koesling, D., and Mittmann, T. (2009). More than a retrograde messenger: nitric oxide needs two cGMP pathways to induce hippocampal long-term potentiation. J. Neurosci. 29, 9344-9350.

Tauck, D. L., and Ashbeck, G. A. (1990). Glycine synergistically potentiates the enhancement of LTP induced by a sulfhydryl reducing agent. Brain Res. 519, 129-132.

Terranova, J. P., Michaud, J. C., Le Fur, G., and Soubrie, P. (1995). Inhibition of long-term potentiation in rat hippocampal slices by anandamide and WIN55212-2: reversal by SR141716 A, a selective antagonist of $\mathrm{CB} 1$ cannabinoid receptors. Naunyn Schmiedebergs Arch. Pharmacol. 352, 576-579.

Teyler, T. J. (1989). Comparative aspects of hippocampal and neocortical longterm potentiation. J. Neurosci. Methods $28,101-108$.

Thibault, O., Gant, J. C., and Landfield, P. W. (2007). Expansion of the calcium hypothesis of brain aging and Alzheimer's disease: minding the store. Aging Cell 6, 307-317.
Thibault, O., Porter, N. M., Chen, K. C., Blalock, E. M., Kaminker, P. G., Clodfelter, G. V., Brewer, L. D., and Landfield, P. W. (1998). Calcium dysregulation in neuronal aging and Alzheimer's disease: history and new directions. Cell Calcium 24, 417-433.

Thomas, M. J., Moody, T. D., Makhinson, M., and O'Dell, T. J. (1996). Activitydependent beta-adrenergic modulation of low frequency stimulation induced LTP in the hippocampal CA1 region. Neuron 17, 475-482.

Toescu, E. C., and Verkhratsky, A. (2007). Role of calcium in normal aging and neurodegeneration. Aging Cell 6, 265.

Toescu, E. C., Verkhratsky, A., and Landfield, P. W. (2004). Ca2+ regulation and gene expression in normal brain aging. Trends Neurosci. 27, 614-620.

Tokuda, K., Zorumski, C. F., and Izumi, Y. (2007). Modulation of hippocampal long-term potentiation by slow increases in ethanol concentration. Neuroscience 146, 340-349.

Tombaugh, G. C., Rowe, W. B., Chow, A. R., Michael, T. H., and Rose, G. M. (2002). Theta-frequency synaptic potentiation in CAl in vitro distinguishes cognitively impaired from unimpaired aged Fischer 344 rats. $J$. Neurosci. 22, 9932-9940.

Tombaugh, G. C., Rowe, W. B., and Rose, G. M. (2005). The slow afterhyperpolarization in hippocampal CA1 neurons covaries with spatial learning ability in aged Fisher 344 rats. J. Neurosci. 25, 2609-2616.

Tong, G., and Jahr, C.E. (1994). Regulation of glycine-insensitive desensitization of the NMDA receptor in outside-out patches. J. Neurophysiol. 72, 754-761.

Tonkikh, A., Janus, C., El-Beheiry, H. Pennefather, P. S., Samoilova, M., McDonald, P., Ouanounou, A., and Carlen, P. L. (2006). Calcium chelation improves spatial learning and synaptic plasticity in aged rats. Exp. Neurol. 197, 291-300.

Tran, T. T., Srivareerat, M., and Alkadhi, K. A. (2010). Chronic psychosocial stress accelerates impairment of long-term memory and late-phase long-term potentiation in an at-risk model of Alzheimer's disease. Hippocampus doi: 10.1002/hipo.20790. [Epub ahead of print].

Trommer, B. L., Shah, C., Yun, S. H., Gamkrelidze, G., Pasternak, E. S., Stine, W. B., Manelli, A., Sullivan, P., Pasternak, J. F., and LaDu, M. J. (2005). ApoE isoform-specific effects on LTP: blockade by oligomeric amyloid-beta1-42. Neurobiol. Dis. $18,75-82$.

Trommer, B. L., Shah, C., Yun, S. H., Gamkrelidze, G., Pasternak, E. S., Ye, G.
L.,Sotak, M.,Sullivan, P.M.,Pasternak, J. F., and LaDu, M.J.(2004). ApoE isoform affects LTP in human targeted replacement mice. Neuroreport 15, 2655-2658.

Tsumoto, T. (1990). Long-term potentiation and depression in the cerebral neocortex. Jpn. J. Physiol. 40, 573-593.

Ullrich, V., Namgaladze, D., and Frein, D. (2003). Superoxide as inhibitor of calcineurin and mediator of redox regulation. Toxicol. Lett. 139, 107-110.

Urban, N. N., Henze, D. A., Lewis, D. A., and Barrionuevo, G. (1996). Properties of LTP induction in the CA3 region of the primate hippocampus. Learn. Mem. 3, 86-95.

Usdin, M. T., Shelbourne, P. F., Myers, R. M., and Madison, D. V. (1999). Impaired synaptic plasticity in mice carrying the Huntington's disease mutation. Hum. Mol. Genet. 8 , 839-846.

Valastro, B., Cossette, J., Lavoie, N., Gagnon, S., Trudeau, F., and Massicotte, G. (2002). Up-regulation of glutamate receptors is associated with LTP defects in the early stages of diabetes mellitus. Diabetologia 45, 642-650.

Valastro, B., Ghribi, O., Poirier, J., Krzywkowski, P., and Massicotte, G. (2001).AMPA receptor regulation and LTP in the hippocampus of young and aged apolipoprotein E-deficient mice. Neurobiol. Aging 22, 9-15.

van Gemert, N. G., Carvalho, D. M., Karst, H., van der Laan, S., Zhang, M., Meijer, O. C., Hell, J. W., and Joels, M. (2009). Dissociation between rat hippocampal $\mathrm{CAl}$ and dentate gyrus cells in their response to corticosterone: effects on calcium channel protein and current. Endocrinology 150, 4615-4624.

van Stegeren, A. H. (2009). Imaging stress effects on memory: a review of neuroimaging studies. Can. J. Psychiatry 54, 16-27.

Vereker,E., O'Donnell, E., Lynch, A., Kelly, A., Nolan, Y., and Lynch, M.A. (2001). Evidence that interleukin-1beta and reactive oxygen species production play a pivotal role in stress-induced impairment of LTP in the rat dentate gyrus. Eur. J. Neurosci. 14, 1809-1819.

Verkhratsky, A., and Toescu, E. C. (1998). Calcium and neuronal ageing. Trends Neurosci. 21, 2-7.

Vogt, K. E., and Canepari, M. (2010). On the Induction of Postsynaptic Granule Cell-Purkinje Neuron LTP and LTD. Cerebellum 9, 284-290.

Wang, H., and Wagner, J. J. (1999). Priming-induced shift in synaptic plasticity in the rat hippocampus. $J$. Neurophysiol. 82, 2024-2028.

Wang, Q., Rowan, M. J., and Anwyl, R. (2004a). Beta-amyloidmediated inhibition of NMDA 
receptor-dependent long-term potentiation induction involves activation of microglia and stimulation of inducible nitric oxide synthase and superoxide. J. Neurosci. 24, 6049-6056.

Wang, Q., Walsh, D. M., Rowan, M. J., Selkoe, D. J., and Anwyl, R. (2004b). Block of long-term potentiation by naturally secreted and synthetic amyloid beta-peptide in hippocampal slices is mediated via activation of the kinases c-Jun $\mathrm{N}$-terminal kinase, cyclin-dependent kinase 5, and p38 mitogen-activated protein kinase as well as metabotropic glutamate receptor type 5. J. Neurosci. 24, 3370-3378.

Wang, Q. W., Rowan, M. J., and Anwyl, R. (2009). Inhibition of LTP by betaamyloid is prevented by activation of beta 2 adrenoceptors and stimulation of the cAMP/PKA signalling pathway. Neurobiol. Aging 30, 1608-1613.

Wang, R. Y., and Arvanov, V. L. (1998). M100907, a highly selective 5-HT2A receptor antagonist and a potential atypical antipsychotic drug, facilitates induction of long-term potentiation in area $\mathrm{CA} 1$ of the rat hippocampal slice. Brain Res. 779, 309-313.

Wang, W., Wang, F., Yang, Y. J., Hu, Z. L., Long, L. H., Fu, H., Xie, N., and Chen, J. G. (2011). The flavonoid baicalein promotes NMDA receptor-dependent long-term potentiation and enhances memory. Br. J. Pharmacol. 162, 1364-1379.

Wang, Y.Y., Liu, S. C., Yang, Z., and Zhang, T. (2010). Impaired hippocampal synaptic plasticity in C6 glioma-bearing rats. J. Neurooncol. doi: 10.1007/s11060010-0447-7. [Epub ahead of print].

Wang, Z., Xu, N. L., Wu, C. P., Duan, S., and Poo, M. M. (2003). Bidirectional changes in spatial dendritic integration accompanying long-term synaptic modifications. Neuron 37, 463-472.

Watabe, A. M., and O'Dell, T. J. (2003). Age-related changes in theta frequency stimulation-induced longterm potentiation. Neurobiol. Aging $24,267-272$.

Watanabe, S., Hoffman, D. A., Migliore, M., and Johnston, D. (2002). Dendritic K ( channels contribute to spike-timing dependent longterm potentiation in hippocampal pyramidal neurons. Proc. Natl. Acad. Sci. U.S.A. 99, 8366-8371.

Watson, J. B., Arnold, M. M., Ho, Y.S., and O’Dell, T. J. (2006). Age-dependent modulation of hippocampal longterm potentiation by antioxidant enzymes. J. Neurosci. Res. 84, 1564-1574.
Watson, J. B., Khorasani, H., Persson, A., Huang, K. P., Huang, F. L., and O'Dell, T. J. (2002). Age-related deficits in long-term potentiation are insensitive to hydrogen peroxide: coincidence with enhanced autophosphorylation of $\mathrm{Ca} 2+/$ calmodulin-dependent protein kinase II. J. Neurosci. Res. 70, 298-308.

Welsby, P. J., Rowan, M. J., and Anwyl, R. (2007). Beta-amyloid blocks high frequency stimulation induced LTP but not nicotine enhanced LTP. Neuropharmacology 53, 188-195.

Weng, S. M., McLeod, F., Bailey, M.E., and Cobb, S. R. (2011). Synaptic plasticity deficits in an experimental model of rett syndrome: long-term potentiation saturation and its pharmacological reversal. Neuroscience.

Wieraszko, A., and Ehrlich, Y. H. (1994). On the role of extracellular ATP in the induction of long-term potentiation in the hippocampus. J. Neurochem. 63 , 1731-1738.

Williams, S., and Johnston, D. (1988). Muscarinic depression of long-term potentiation in CA3 hippocampal neurons. Science 242, 84-87.

Wilsch, V. W., Behnisch, T., Jager, T., Reymann, K. G., and Balschun, D. (1998). When are class I metabotropic glutamate receptors necessary for long-term potentiation? J. Neurosci. 18, 6071-6080.

Winder, D. G., Mansuy, I. M., Osman, M., Moallem, T. M., and Kandel, E. R. (1998). Genetic and pharmacological evidence for a novel, intermediate phase of long-term potentiation suppressed by calcineurin. Cell 92, 25-37.

Wolf, O. T. (2009). Stress and memory in humans: twelve years of progress? Brain Res. 1293, 142-154.

Wright, J. W., Kramar, E. A., Myers, E. D., Davis, C. J., and Harding, J. W. (2003). Ethanol-induced suppression of LTP can be attenuated with an angiotensin IV analog. Regul. Pept. 113, 49-56.

Wu, L. J., Mellstrom, B., Wang, H., Ren, M., Domingo, S., Kim, S. S., Li, X. Y., Chen, T., Naranjo, J. R., and Zhuo, M. (2010). DREAM (downstream regulatory element antagonist modulator) contributes to synaptic depression and contextual fear memory. Mol. Brain 3, 3 .

Wu, W. W., Oh, M. M., and Disterhoft, J. F. (2002). Age-related biophysical alterations of hippocampal pyramidal neurons: implications for learning and memory. Ageing Res. Rev. 1, 181-207. Xia, Z., and Storm, D. R. (2005). The role of calmodulin as a signal integrator for synaptic plasticity. Nat. Rev. Neurosci. 6, 267-276.

Xie, H., Leung, K. L., Chen, L., Chan, Y. S., Ng, P. C., Fok, T. F., Wing, Y. K., Ke, Y., Li, A. M., and Yung, W. H. (2010). Brain-derived neurotrophic factor rescues and prevents chronic intermittent hypoxia-induced impairment of hippocampal long-term synaptic plasticity. Neurobiol. Dis. 40, 155-162.

Xu, B., Gottschalk, W., Chow, A., Wilson, R. I., Schnell, E., Zang, K., Wang, D., Nicoll, R. A., Lu, B., and Reichardt, L. F. (2000). The role of brain-derived neurotrophic factor receptors in the mature hippocampus: modulation of long-term potentiation through a presynaptic mechanism involving TrkB. J. Neurosci. 20, 6888-6897.

Xu, J., and Kang, J. (2005). The mechanisms and functions of activitydependent long-term potentiation of intrinsic excitability. Rev. Neurosci. 16 311-323.

Xu, L., Anwyl, R., and Rowan, M. J. (1997). Behavioural stress facilitates the induction of long-term depression in the hippocampus. Nature 387 , 497-500.

Xu, N.L., Ye, C. Q., Poo, M.M., and Zhang, X. H. (2006). Coincidence detection of synaptic inputs is facilitated at the distal dendrites after long-term potentiation induction. J. Neurosci. 26, 3002-3009.

Yamazaki, Y., Kaneko, K., Fujii, S., Kato, H., and Ito, K. (2003). Long-term potentiation and long-term depression induced by local application of ATP to hippocampal CA1 neurons of the guinea pig. Hippocampus 13, 81-92.

Yamin, G. (2009). NMDA receptordependent signaling pathways that underlie amyloid beta-protein disruption of LTP in the hippocampus. J. Neurosci. Res. 87, 1729-1736.

Yoshioka, M., Yamazaki, Y., Fujii, S., Kaneko, K., Kato, H., and Mikoshiba, K. (2010). Intracellular calcium ion dynamics involved in long-term potentiation in hippocampal CA1 neurons in mice lacking the IP3 type 1 receptor. Neurosci. Res. 67, 149-155.

Yun, S. H., Park, K. A., Kwon, S., Woolley, C. S., Sullivan, P. M., Pasternak, J. F., and Trommer, B. L. (2007). Estradiol enhances long term potentiation in hippocampal slices from aged apoE4TR mice. Hippocampus 17, 1153-1157.

Zakharenko, S. S., Zablow, L., and Siegelbaum, S.A. (2001). Visualization of changes in presynaptic function during long-term synaptic plasticity. Nat. Neurosci. 4, 711-717.
Zeng, Y., Zhao, D., and Xie, C. W. (2010). Neurotrophins enhance CaMKII activity and rescue amyloid-beta-induced deficits in hippocampal synaptic plasticity. J. Alzheimers Dis. 21, 823-831.

Zhao, D., Watson, J. B., and Xie, C. W. (2004). Amyloid beta prevents activation of calcium/calmodulin-dependent protein kinase II and AMPA receptor phosphorylation during hippocampal long-term potentiation. $J$. Neurophysiol. 92, 2853-2858.

Zhao, W. F., Ruan, D. Y., Xu, Y. Z., Chen, J. T., Wang, M., and Ge, S. Y. (1999). The effects of chronic lead exposure on long-term depression in area CA1 and dentate gyrus of rat hippocampus in vitro. Brain Res. 818, 153-159.

Zhou, S. Y., Xu, S. J., Yan, Y. G., Yu, H. M., Ling, S. C., and Luo, J. H. (2011). Decreased purinergic inhibition of synaptic activity in a mouse model of Niemann-Pick disease type C. Hippocampus 21, 212-219.

Zhuo, M., Hu, Y., Schultz, C., Kandel, E. R., and Hawkins, R. D. (1994). Role of guanylyl cyclase and cGMP-dependent protein kinase in long-term potentiation. Nature 368, 635-639.

Zhuo, M., Laitinen, J. T., Li, X. C., and Hawkins, R. D. (1999). On the respective roles of nitric oxide and carbon monoxide in long-term potentiation in the hippocampus. Learn. Mem. 6, 63-76.

Zhuo, M., Small, S. A., Kandel, E. R., and Hawkins, R. D. (1993). Nitric oxide and carbon monoxide produce activity-dependent long-term synaptic enhancement in hippocampus. Science 260, 1946-1950.

Conflict of Interest Statement: The author declares that the research was conducted in the absence of any commercial or financial relationships that could be construed as a potential conflict of interest.

Received: 16 March 2011; accepted:29April 2011; published online: 20 May 2011.

Citation: Kumar A (2011) Long-term potentiation at CA3-CA1 hippocampal synapse with special emphasis on aging, disease, and stress. Front. Ag. Neurosci. 3:7. doi: 10.3389/fnagi.2011.00007

Copyright $\odot 2011$ Kumar. This is an openaccess article subject to a non-exclusive license between the authors and Frontiers Media SA, which permits use, distribution and reproduction in other forums, provided the original authors and source are credited and other Frontiers conditions are complied with. 